\title{
Sproglige generationsforskelle på de sociale medier
}

\author{
MARIANNE HAUGAARD HANSEN OG \\ ANDREAS CANDEFORS STÆHHR
}

\begin{abstract}
I takt med at de sociale medier i stigende grad bliver anvendt på tværs af aldersgrupper, opstår der nye kommunikationskulturer og normer for sprogbrug, som danner grobund for oplevelser af sproglige generationsforskelle. I denne artikel undersøger vi, hvordan unge (15-18 år) og deres forældre giver udtryk for sådanne sproglige generationsforskelle i private online kontekster. Vi fokuserer særligt på forskelle i forhold til brug af emojis og forkortelser samt orientering mod forskellige normer for tegnsætning, sproglig korrekthed og korrekturlæsning. Vi undersøger både, hvordan sådanne sproglige generationsforskelle artikuleres i interviews med de unge og deres forældre, og hvordan de kommer til udtryk i deres online interaktioner. Artiklen bidrager med ny viden om digitalt medieret sprogbrug i nutidige familier og giver en indsigt $i$, hvordan unge og voksne på trods af deres forskellige forventninger til online interaktion kan tilpasse sig hinandens sprogbrug, når de skriver sammen online.
\end{abstract}

EMNEORD: normativitet, registergørelse, akkommodation, sproglig etnografi

\section{INTRODUKTION}

"[...] jeg tror, jo ældre man bliver, jo mere vild er man med de der emojis" (Lea, 15 år).

Ifølge Lea anvender hendes mor og mormor flere emojis, end hun selv gør, når de skriver sammen på de sociale medier. Dette gør sig særligt gældende i deres private online korrespondancer over sms og via Facebook Messenger, som er de sociale medier, vi primært fokuserer på i denne undersøgelse. Beskrivelser som denne, hvor forældre og bedsteforældre fremstilles som særligt flittige emoji-brugere, er hyppigt forekommende blandt deltagerne i vores undersøgelse af sprog og sociale medier i familien. Ydermere bidrager sådanne beskrivelser til en nuancering af de stereotype forestillinger, der findes om forholdet mel- 
lem alder, medie- og sprogbrug i den offentlige debat, hvor unge ofte fremstilles som de mest kreative sprogbrugere og som 'online pionerer' (Livingstone \& Haddon 2009:1), ligesom de ofte gøres til hovedpersoner i panikdiskurser om online sprogbrug (Thurlow 2006; Stæhr 2016b). I dag har de ældre generationer også taget de sociale medier til sig (Danmarks Statistik 2018) og i takt med, at de i stigende grad kommunikerer med hinanden, deres børn og måske også børnebørn via skrift, opstår der nye normer for online sprogbrug, etablering af nye kommunikationskulturer og forventninger til, hvad der karakteriserer succesfuld online interaktion. At både unge og voksne i dag er flittige brugere af sociale medier, danner således også grobund for en oplevelse af sproglig forskelligartethed generationerne imellem, og det er netop sådanne sproglige generationsforskelle, vi fokuserer på i denne artikel.

Det er ikke nyt, at man inden for sociolingvistikken interesserer sig for sproglig variation på tværs af aldersgrupper, og tillægger alder stor forklaringskraft i undersøgelser af sproglige forandringsprocesser (Labov 1972: 136; Coupland 2004: 69). Alder har også været behandlet som et undersøgelsesobjekt i sig selv, hvor man har interesseret sig for generationssprog for at give et billede af hvilke sproglige træk, der kan anskues som generationsspecifikke (fx Eckert 1997, Coupland 2004, Cheshire 2005; Rathje 2010). Her har der enten været fokus på én generations sproglige træk ( $\mathrm{fx}$ om der er træk, der kan associeres særligt med "voksen-" eller "ungdomssprog"), eller også har der været fokus på interaktionen på tværs af generationer (fx om unge og voksne talere akkommoderer sprogligt i bestemte situationer) (Rathje 2010: 33). Der er imidlertid forskel på, hvor meget opmærksomhed unges og voksnes sprogbrug har fået inden for sociolingvistikken. Overordnet set er ungdomssprog et velundersøgt fænomen, mens voksnes sprogbrug har fået knap så meget opmærksomhed - særligt hvad angår undersøgelser af alder ud fra et socialt og identitetsmæssigt perspektiv (Eckert 1997, Coupland 2004, Cheshire 2005). Dette skyldes muligvis, at ungdomssprog har været anskuet som (eller måske endda ophøjet til) omdrejningspunkt for det moderne, nyskabende og kreative - eller som Eckert (1997: 1) beskriver det: "adolescents are the linguistic movers and shakers". Et lignende billede tegner sig inden for den mediefokuserede sociolingvistik, hvor ungdomskulturelle praksis- 
ser og unges online sprogbrug ligeledes har tiltrukket stor forskningsmæssig opmærksomhed (Barton \& Lee 2010:13). Dette er imidlertid ikke ensbetydende med, at voksnes online sprogbrug er ubeskrevet (se fx Hougaard 2004, Kemp et al. 2014, Pérez-Sabater \& Montero-Fleta 2015, Andersen 2015, Tagg \& Seargant 2017, Monka 2018, Andersen \& Rathje 2019). Endvidere synes der inden for de seneste år at være en stigende interesse for digitalt medieret sprogbrug i familiekontekster (se fx Madianou \& Miller 2013, Lanza \& Lexander 2019, Lexander \& Androutsopoulos 2021, Stæhr \& Nørreby under udgivelse), men dette har endnu ikke resulteret i en omfattende forskningslitteratur (se Lanza \& Lexander 2019 for et overblik). Således mangler der stadig viden om digitalt medieret sprogbrug i nutidige familier.

I denne artikel fokuserer vi på sproglige generationsforskelle i familiemedlemmers interaktionelle praksisser i private online kontekster. Mere specifikt undersøger vi, hvilke sproglige karakteristika og normer for sprogbrug, der kendetegner henholdsvis unge og deres forældres digitalt medierede interaktioner. Vi belyser dette ved henholdsvis at undersøge, hvilke normer for sprogbrug (herunder hvilke sproglige generationsforskelle), der artikuleres i deltagernes metasproglige beretninger $\mathrm{i}$ interviews, og hvordan disse normer og forskelle kommer til udtryk i deltagernes faktiske online sprogbrug. Vi fokuserer særligt på brugen af forkortelser, korrektur- og tegnsætningspraksisser, emojibrug og beskedlængde, idet disse indgår i både de unges og deres forældres fortællinger om sproglige generationsforskelle. Endelig undersøger vi også, hvordan de unge og deres forældre sprogligt tilpasser sig hinanden, når de interagerer online via sms'er eller Facebook Messenger. Artiklen er struktureret således, at vi indledningsvis redegør for begreberne kommunikativ tilpasning og sproglig normativitet. Herunder beskriver vi, hvordan gruppenormer opstår og etableres som et led i registergørelsesprocesser. Herefter ser vi nærmere på alder som begreb samt den kritik begrebet har været underlagt inden for sociolingvistisk forskning. I forlængelse heraf redegør vi for begreberne 'ungdoms-' og 'voksensprog' samt giver en kort beskrivelse af de online sproglige praksisser og fænomener, som udgør omdrejningspunktet for vores analyser af sproglige generationsforskelle. Vores analyser er inddelt i to dele. I den første del giver vi et indblik $\mathrm{i}$, hvad der kendetegner de to generationers normer 
for online sprogbrug, og hvilke sproglige forskelle vi finder mellem de to generationer. I den anden del fokuserer vi på, hvordan de unge og deres forældre til trods for deres sproglige forskelligheder tilpasser sig hinanden, når de skriver sammen på sms eller via Facebook Messenger.

\section{SPROGLIG NORMATIVITET OG KOMMUNIKATIV TILPASNING}

Digitalt medieret sprogbrug har længe været en del af mange familiers kommunikationskulturer og kan defineres som kommunikative praksisser, der involverer brugen af digitalt medieret tekst, billeder, tale og andre betydningsbærende semiotiske ressourcer (så som emojis, emotikoner og sammensætninger af andre digitale tegn) (Mortensen \& Stæhr 2018: 14). I denne artikel fokuserer vi på digitalt medieret sprogbrug i private online kontekster, som er kendetegnet ved at fordre intime samtaler (Ellison \& boyd 2013). I vores data er disse private online kontekster ydermere kendetegnet ved, at samtaledeltagerne kender hinanden fra offline kontekster ( $f x$ en gymnasieklasse, venindegruppe eller familie). Som med al anden sprogbrug er digitalt medieret sprogbrug normativt organiseret $-\mathrm{dvs}$. bundet op på regler og normer for passende og upassende social og sproglig opførsel. Ifølge Agha (2007: 124) kan normativitet gradinddeles i tre (nogle gange overlappende) niveauer. Det forste niveau vedrører det, Agha definerer som eksternt observerbare normer. Dette er normer, der afspejler statistisk målbare adfærdsmønstre blandt en gruppe mennesker (fx når en sprogforsker med statistiske værktøjer peger på et bestemt sprogligt træk som karakteristisk for en gruppe sprogbrugere). På dette niveau er sprogbrugerne ikke nødvendigvis refleksive omkring, at et bestemt sprogligt handlemønster udgør en norm. Det er de imidlertid på det andet niveau, som vedrører sproglige adfærdsmønstre, der bliver opfattet og behandlet som 'normale' blandt en gruppe mennesker. Vi vender tilbage til, hvordan sådanne gruppenormer opstår. Aghas (2007) tredje niveau vedrører de normative standarder. En standardnorm er ikke kun gældende for en bestemt gruppe, men er, grundet dens institutionelle og ideologiske status, ophøjet til at være en samfundsnorm. Et eksempel på dette er den ortografiske standard (jf. retskrivningsnormen), som på grund af sin høje status i samfundet anses som et (sprog)ideologisk 
omdrejningspunkt, hvorfra alle andre normer for sprogbrug afviger (Silverstein 2003:219). På grund af standardens høje sociale status, kan det være socialt stigmatiserende at afvige fra denne norm, hvilket vi også skal se eksempler på i vores analyser. Det er bl.a. det, der er på spil, når deltagerne $\mathrm{i}$ vores undersøgelse kommenterer på hinandens korrekturlæsningspraksisser - eller mangel på samme.

Normer for sprogbrug er socialt konstruerede i interaktionen mellem mennesker og har at gøre med hvilke sproglige registre, der opleves som passende at anvende i forskellige sociale situationer, på bestemte medier eller i interaktioner med bestemte personer (Mortensen \& Stæhr 2018:15). Den proces, hvorved sprog og herunder normer for sprogbrug bliver til, betegnes af Agha (2007) med begrebet registergørelse ('enregisterment'). Mere præcist beskriver dette begreb, hvordan forskellige måder at tale (eller skrive) på bliver knyttet til sociale aktiviteter, normer for sprogbrug, forskellige individer eller generationer. Disse forbindelser mellem sproglige og semiotiske tegn (i brug), normer, værdier og sociale handlinger kaldes også indeksikalske forbindelser (Ochs 1992, Silverstein 2003). Det er netop sådanne forbindelser mellem sprogbrug og normer, værdier og grupper vi fokuserer på i vores analyser og som biddrager med viden om igangværende registergørelsesprocesser. Når sådanne indeksikalske forbindelser bliver genkendelige for en større eller mindre gruppe af mennesker, opstår der en gruppenorm (Agha 2007:126). Det er altså det, der er på spil, når deltagerne i vores undersøgelse betegner bestemte måder at bruge digitalt medieret sprogbrug på som henholdsvis et ungdoms- eller voksenfænomen. Gruppegenererede normer konstrueres (og etableres) både gennem implicitte og eksplicitte metasproglige aktiviteter (Agha 2003). Normer for sprogbrug etableres implicit gennem selve den handling at bruge sprog (altså i interaktionen med andre) og etableres eksplicit, når sprogbrugere taler om sprogbrug, retter hinanden eller på andre måder orienterer sig mod hvilke former for sprogbrug, der er mere passende end andre. Normer kan således også gøres til genstand for forhandling, hvis sprogbrugerne ikke er enige om, hvad der er passende eller upassende sprogbrug i en bestemt situation. Sådanne forhandlinger foregår på samme måde gennem både implicitte og eksplicitte metasproglige aktiviteter. Det vil altså sige, at normer både konstrueres og forhandles, 
når mennesker bruger sprog, og når de taler om sprog. I denne artikel analyserer vi både normer for sprogbrug på baggrund af de normer, vi kan observere i deltagernes online interaktioner, og på baggrund af de normer, som deltagerne artikulerer i interviews, og vi fokuserer i vores analyser både på orientering mod gruppegenererede normer og den standardortografiske norm.

Både standard- og gruppegenererede normer kan sameksistere i et samfund eller for den sags skyld i en familie. Det skal vi se eksempler på i vores analyser, hvor henholdsvis de unge og deres forældre giver udtryk for at have forskellige normer for, hvordan man kommunikerer på de sociale medier. Dette er et udtryk for, at sproglig normativitet er polycentrisk organiseret (Blommaert 2010), hvilket betyder, at sprogbrugere kan orientere sig mod flere forskellige normcentre alt efter, hvilken kommunikativ situation de indgår i. Nogle gange kan det være forbundet med status at orientere sig mod normer forbundet med bestemte institutioner (Retskrivningsordbogen eller skolen), mens status andre gange kan opnås gennem orientering mod normer forbundet med bestemte grupper (jævnaldrende venner eller familien) eller individer (den seje dreng i klassen eller ens mor). Man kan derfor trække på forskellige normer til bestemte sociale formål, hvorfor man i en given situation fx kan følge én norm samtidig med, at man overtræder en anden. Dette er eksempelvis tilfældet, når unge skriver med hinanden og overholder deres 'egne' normer, men samtidig afviger fra standarden. Blandt de unge deltagere opleves sådanne afvigelser fra standarden i deres private online korrespondancer ofte som normale, mens deres forældre derimod typisk vil se sådanne afvigelser som stavefejl eller sjusk, som vi vil vise i vores analyser. I sådanne tilfælde kan man tale om, at bestemte måder at bruge sprog på fremstår markeret, i den forstand at den pågældende sprogbrug behandles som 'unormal' eller upassende i forhold til den gældende (og situationelt bestemte) norm. Omvendt kan sprogbrug også fremstå umarkeret, hvis sprogbrugerne overholder og deler den samme opfattelse af, hvilke normer for sprogbrug, der gælder i en given situation.

Selvom voksne og unge ikke altid har den samme opfattelse af passende og upassende sprogbrug, og voksen- og ungdomssprog ofte an- 
skues som værende i opposition til hinanden (Jørgensen 2001), er det ikke ualmindeligt, at unge og voksne tilpasser sig hinanden sprogligt af forskellige årsager. Sprogbrugere har nemlig en evne til at tilpasse sig den sociale kontekst, de indgår i. Ifølge akkommodationsteorien (se fx Dragojevic et al. 2016) udgør kommunikativ tilpasning en fundamental social færdighed og bunder i et behov for at kunne lette forståelsen imellem samtalepartnere og for at forhandle den sociale afstand mellem dem. Dragojevic et al. (2016) beskriver tre forskellige grundlæggende akkommodationsstrategier: Sprogbrugere kan vælge at konvergere (nærme sig den anden), divergere (afvige fra den anden), eller opretholde deres eksisterende måde at kommunikere på. Konvergerende adfard opfattes ofte som et tegn på velvillighed, samarbejde og som en indstilling til at lette kommunikationen samt et ønske om at opnå noget socialt. Det modsatte gør sig gældende for divergerende adfard, der som regel opfattes negativt og som en strategi til at opretholde og fremhæve sociale forskelle, både på individ- og gruppeniveau, og til at mindske forståelsen. De to strategier er således tæt forbundet med identitetsarbejde og markering af gruppetilhørsforhold. Konvergerende og divergerende adfærd er motiveret eller påvirket af sociokulturelle og sproglige normer, og den enkelte er derfor begrænset af, hvilke sproglige repertoirer vedkommende har til rådighed. Man kan derfor ikke tilpasse sig en stil, man ikke behersker, har kendskab til eller rettighed til at anvende. I sådanne situationer må man derfor trække på nogle af de ressourcer, man har adgang til, og eksempelvis tilpasse sig i taletempo og kropssprog eller i tastetempo, beskedlængde og emojibrug, hvilket vi skal se eksempler på i vores analyser.

\section{ALDER OG ONLINE SPROGLIG STIL}

Kategorierne "unge" og "voksne/forældre" er centrale for vores undersøgelse, idet de udgør kategorier, som deltagerne orienterer sig imod i deres beskrivelser af sproglige generationsforskelle online. Sådanne alderskategorier kan imidlertid ikke ukritisk kobles til sproglige stile, ligesom alder som begreb (og undersøgelsesobjekt) har været underlagt kritik inden for sociolingvistisk forskning. Eckert (1997:156) fremhæver eksempelvis, at der er forskel på kronologisk, biologisk og social alder. Social alder (eller kontekstuel alder, som er det begreb Coupland (1997) 
anvender) er tilknyttet særlige livsbegivenheder, familiestatus eller juridisk status. Det at være 'ung' eller 'voksen' er altså fleksible sociale kategorier (eller identiteter), som konstrueres (ofte i relation til hinanden) ved hjælp af forskellige sproglige og semiotiske ressourcer (Coupland 2004, Leppänen 2007). Forældrene i vores undersøgelse er mellem 33 og 56 år gamle. De kan på baggrund af deres kronologiske alder derfor ikke betegnes som en del af den samme generation. Dog kan de i kraft af deres sociale eller kontekstuelle alder (jf. deres fælles status som forældre til teenagebørn) betragtes som en samlet gruppe. På samme måde kan man heller ikke beskrive ungdoms- eller voksensprog som en stil eller et register, der er knyttet til en fysiologisk definerbar samfundsgruppe kaldet "unge" eller "voksne". I stedet skal sådanne sproglige stile anskues som bestående af sæt af sproglige og semiotiske træk, der inden for bestemte sociale, normative og kulturelle rammer anvendes til at konstruere og forhandle ungdoms- eller voksenkulturer, -praksisser og -identiteter (Leppänen 2007:151), og det er på baggrund af sådanne sproglige konstruktioner og forhandlinger, at man kan skelne "voksne" og "unge" fra hinanden (Androutsopoulos \& Georgakopolou 2004), hvilket vi vil vise i vores analyser. I det følgende redegør vi for nogle af de sproglige fænomener og kommunikative praksisser, som deltagerne i vores undersøgelse anvender i deres skelnen mellem voksnes og unges online sprogbrug - herunder hverdagsskriftsproglige forkortelser, beskedlængde og emojis.

Emojis er efterhånden et velundersøgt fænomen inden for både medieog sprogforskning, hvor deres historiske ophav og deres interaktionelle, pragmatiske og affektive funktioner er blevet belyst (se bl.a. Dresner \& Herring 2010, Stark and Crawford 2015, Danesei 2017 eller Hougaard 2020). I forhold til denne artikels fokus anskuer vi emojis som kontekstualiseringsmarkører (Gumperz 1982), idet de ofte udgør en central semiotisk ressource i forhold til en ytrings pragmatiske betydning (Dresner \& Herring 2010), hvorfor emojis bidrager til, hvordan sprogbrugere skal opfatte den ytring eller korrespondance, de er en del af. Endvidere er emojis kulturelt ladede og flertydige på en måde, hvor brugen af dem kræver specifikke sproglige kompetencer og færdigheder samt kulturel viden (Danesi 2017). Derfor indgår emojis på linje med andre sproglige og semiotiske 
træk også i registergørelsesprocesser blandt unge og voksne sprogbrugere, hvorved de gennem forskellige eksplicitte og implicitte metasproglige aktiviteter bliver associeret med bestemte sprogbrugere, stile, normer og indeksikalske værdier. Det samme gælder brugen af forskellige hverdagsskriftsproglige forkortelser.

Forkortelser er et sprogligt fænomen, der både forbindes med tale- og skriftsprog. I forhold til skriftsprog kan forkortelser, ifølge Jensen og Rathje (2004: 9), defineres som "[...] et ord der ikke er skrevet helt ud". Endvidere har forkortelser til formål at være henholdsvis pladsog tidsbesparende for den, der skriver. Fra et standardortografisk perspektiv kan man overordnet set tale om to typer af forkortelser - dem, som er i overensstemmelse med standardortografien (og anbefales i eksempelvis Retskrivningsordbogen) og dem, der kan kategoriseres som alternative eller tilhørende en bestemt sproglig stil, genre eller grupper af mennesker. I denne artikel fokuserer vi på brug af alternative forkortelser, der forekommer i hverdagsskriftsproget på de sociale medier. Eksempler på sådanne forkortelser kan være omg for 'oh my god', $k$ for 'kæreste' eller 'ok', $w t f$ for 'what the fuck' eller, idk for 'I don't know' (se også Hougaard 2014:50). Sådanne forkortelser bliver inden for den sprogfokuserede medieforskning forbundet med henholdsvis chatstil (Hougaard 2004), sms-sprog (Rotne 2009) eller hverdagsskriftsprog generelt (Stæhr 2015, jf. 'vernacular writing' Androutsopoulos 2011). $\mathrm{Vi}$ anvender i denne artikel termen hverdagsskriftsproglige forkortelser, idet deltagerne i vores undersøgelse beskriver denne type forkortelser som værende i opposition til den ortografiske standard. Hverdagsskriftsproglige forkortelser i digitalt medieret sprogbrug kan have forskellige kommunikative funktioner. Ud over at pege på en bestemt sproglig stil, som bl.a. er tilfældet i vores data, kan de også indgå i en økonomiseringsstrategi, der har til formål at spare tid og plads (Hougaard 2014:49). Det samme gør sig gældende for kort beskedlangde, der ifølge Androutsopoulos (2011:149), også kan indgå som led i en sproglig økonomiseringsstrategi. Tidligere har korte skriveture (med så få tegn som muligt) været forbundet med tegnbegrænsninger og det forhold, at det kostede penge at sende sms-beskeder. I dag, hvor de fleste sender beskeder 'gratis' og ikke er begrænsede i antallet af tegn, er korte skrive-ture i højere grad motiveret af høj kommunikationshastighed i 
kvasi-synkrone beskedudvekslinger, hvilket vi bl.a. skal se eksempler på i vores analyser af de unges online beskeder. Inden vi ser nærmere på dette, redegør vi for artiklens empiriske grundlag.

\section{DATA OG METODE}

Denne undersøgelse er en del af det kollektive forskningsprojekt SoMeFamily (Sprog og Sociale Medier i Familien). Projektet er metodologisk forankret i et sprogligt etnografisk perspektiv (Rampton et. al. 2007, Stæhr 2018) og har til formål at undersøge, hvilke sociale og kommunikative funktioner sociale medier udfylder i familien. Over en periode på 7 måneder i 2018-2019 udførte vi online og offline etnografi (Androutsopoulos \& Stæhr 2018) blandt en gruppe unge (15-18 år) og deres familier. Feltarbejdet blev udført af fem forskere og forløb i to forbundne faser.

I feltarbejdets forste fase fulgte vi de unge i to gymnasieklasser (59 elever) på et københavnsk gymnasium over en periode på 3 måneder. Feltarbejdet bestod af ca. 80 besøg på gymnasiet, hvor en eller flere feltarbejdere udførte deltagerobservationer blandt de unge i timerne og i frikvarterne. Udover at interagere og socialisere med eleverne bad vi de elever, der havde lyst, om at foretage selvoptagelser i forskellige skoleog fritidssituationer. Herudover oprettede vi forskerprofiler på Instagram, Facebook og Snapchat, hvilket muliggjorde, at vi kunne indsamle online data og følge de unges sociale liv online. Af etiske hensyn bad vi de unge om at sende os venneanmodninger på disse sociale medier. Derudover gjorde vi kontinuerligt opmærksom på, at vi var til stede online, når vi talte med de unge i forskellige sammenhænge på skolen. I denne fase udførte vi også semistrukturerede gruppeinterviews med de unge, hvor vi talte med dem om deres brug af sociale medier og deres sproglige hverdagsliv med familie og venner. Vi udførte desuden såkaldte media go-along-samtaler (Jørgensen 2016) med udvalgte unge, hvorved vi fik indsigt i deres mere private online korrespondancer (såsom sms'er og Messenger-beskeder). Media go-along-samtaler er en type samtale, hvor man under samtalen ser på (og optager) deltagernes telefon- eller computerskærme, samtidig med at de fortæller om det, de viser på skærmen. I feltarbejdets anden fase sendte vi et brev til alle de unges familier, hvor vi spurgte, om vi måtte fortsætte feltarbejdet 
hjemme hos de unge. Det var der 14 familier, der indvilligede i. Over en periode på fire måneder besøgte en feltarbejder derfor hver familie to til fire gange. Under disse besøg udførte feltarbejderen interviews og media go-along-samtaler med forældrene (33-56 år) og nogle gange med mindre søskende. Parallelt med disse forskeraktiviteter udførte vi også online etnografi ved at følge (og lave screenshots af) familiemedlemmernes aktiviteter på Facebook og Instagram. På trods af aldersspredningen i forældregruppen har de som nævnt det til fælles, at de har børn i teenagealderen (15-18 år).

Datagrundlaget for denne artikel udgøres af gruppeinterviews med 59 unge, interviews med forældrene fra de 14 familier samt media go-along-samtaler med 12 af de unge og 15 af forældrene. Media go-along-samtalerne giver adgang til skærmdata af og udtalelser om korrespondancer på Facebook Messenger, Snapchat, e-mail, sms'er osv. Alle interviewuddrag og media go-along-samtaler er udskrevet efter minimale CA-konventioner (se transskriptionsnøglen sidst i artiklen). Analyserne fokuserer på digitalt medieret sprogbrug, som udspiller sig i private grupper eller tråde på Facebook Messenger eller i form af sms-korrespondancer mellem to eller flere deltagere, der kender hinanden på forhånd. Mere specifikt er der tale om en Messenger-gruppe med 9 gymnasieelever (se uddrag 2), en Messenger-gruppe bestående af 5 veninder i 40-årsalderen (se uddrag 9) og sms-beskeder mellem teenagere og deres forældre. Alle data, som er anvendt i denne artikel, er desuden indholdskodet i programmet Atlas.ti, bl.a. med koder som "generationsforskelle" og "normer for sprogbrug". Endelig bygger vores analyser på de indsigter, vi har opnået gennem det etnografiske feltarbejde på skolen og hjemme hos familierne samt de observationer, vi har gjort os ved at være til stede i to Messenger-grupper, der blev oprettet af gymnasieklasserne. Begge grupper indeholder daglige korrespondancer mellem de unge over en periode på ca. 4 måneder.

\section{NORMER FOR SPROGBRUG OG SPROGLIGE GENERATIONSFORSKELLE}

I denne første del af analysen fokuserer vi på de sproglige generationsforskelle og normer for sprogbrug, der henholdsvis kommer til udtryk i deltagernes metasproglige refleksioner i interviews og i deres online 
sproglige praksisser. Vi fokuserer på sproglige generationsforskelle, der relaterer sig til brugen af og normer for forkortelser (5.1), korrekturlæsning (inkl. tegnsætning) (5.2), emojis (5.3) og beskedlængde (5.4), som er former for sprogbrug, hvor de unge og deres forældre oplever forskelle på tværs af generationerne.

\subsection{Brug af hverdagssproglige forkortelser online}

Både de unge og deres forældre karakteriserer online brug af hverdagsskriftssprogligeforkortelsersometungdomsfænomen. Derforkanbrugen af forkortelser altså anskues som en generationsforskel. I uddrag 1 skal vi se nærmere på, hvordan hverdagssproglige forkortelser udgør et centralt element i de unges beskrivelser af deres egen online sprogbrug. Forud for uddraget fortæller de om, hvordan de kommunikerer på de sociale medier. Intervieweren spørger i denne forbindelse ind til, hvad de kalder denne form for sprogbrug:

\section{Uddrag 1: "Ja der er mange forkortelser"}

Gruppeinterview, deltagere: Louis (LOU) 15 år, Hannan (HAN) 16 àr, Tobias (TOB) 18 år og Kaya 16 àr. Interviewer: (Andreas) XAS

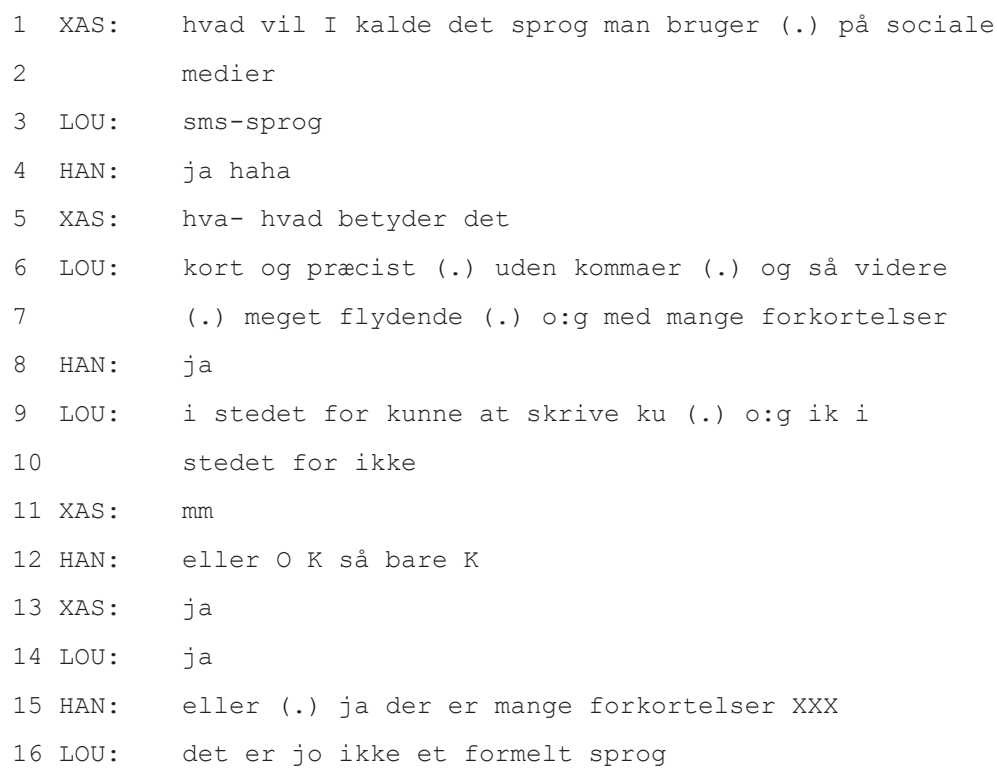


20 XAS: $\mathrm{mm}$

21 TOB: nej (.) nej det er rigtig

22 HAN: eller for eksempel I don't know

23 XAS: ja

24 HAN: det er bare I D K

25 XAS: okay

26 HAN: så det sådan ved man godt de der forkortelser

Forkortelser bliver i dette uddrag associeret med sms-sprog (1. 3), som er en sproglig stil, der står i kontrast til den standardortografiske norm (l. 16 og 18). Sammen med korte beskeder og ingen kommatering (1. 6-7) beskrives mange forkortelser (1. 15) som et online ungdomstræk. I forhold til forkortelsernes kommunikative funktion udgør de en ressource til at opretholde en meget flydende (1. 7) kommunikativ stil. Dette stemmer godt overens med Rathjes (2018) undersøgelse af unges sms'er, hvor hun ligeledes beskriver, hvordan unge forbinder kortformer med økonomisering og oralitet. Endelig fremstår de unges brug af hverdagsskriftsproglige forkortelser i dette uddrag som en umarkeret eller normaliseret sproglig praksis (1. 26), hvilket også stemmer overens med de observationer vi har gjort os under vores online etnografiske feltarbejde i de to Messenger-grupper, der blev oprettet af de to gymnasieklasser. Denne umarkerede brug af hverdagssproglige forkortelser skal vi se et eksempel på i uddrag 2, som er en Messenger-korrespondance mellem fem unge deltagere. Maya har postet et billede i gruppen, der forestiller Lea som barn. Billedets motiv er ikke relevant for analysen og er derfor fjernet af anonymiseringshensyn. Billedet udgør omdrejningspunktet for den efterfølgende interaktion: 


\section{Uddrag 2: "Omg..."}

Messenger-korrespondance. Deltagere: Nabil (16 år), Lea (15 år), Maya (16 år), Molly (16 år) og Mark (16 år)

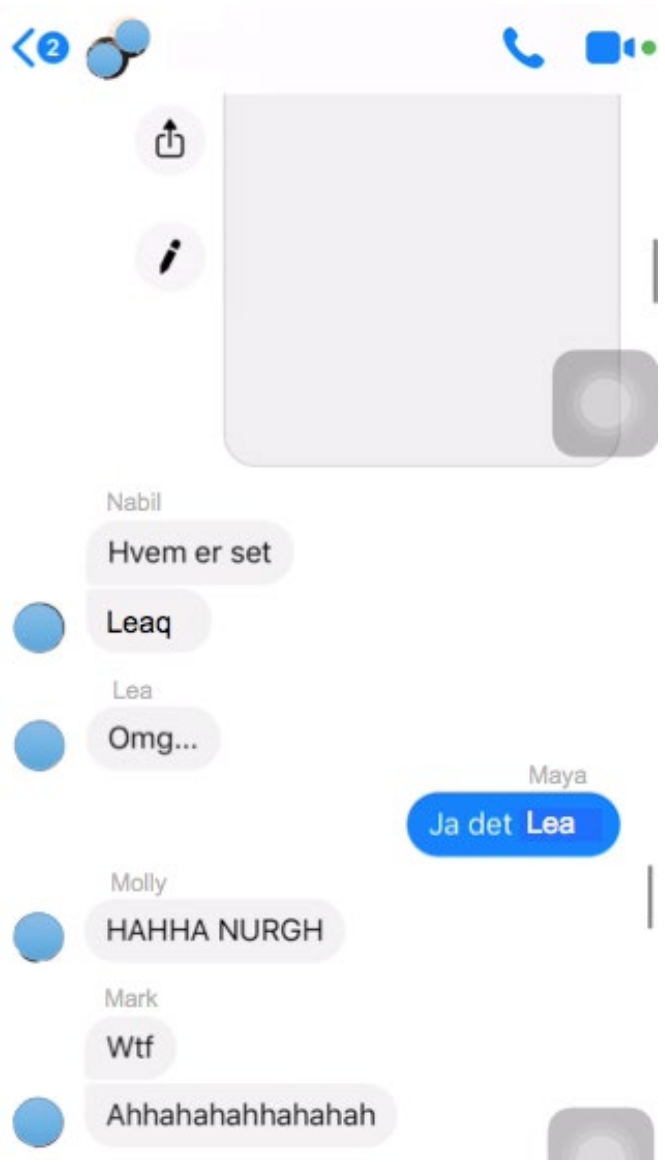

Denne korrespondance er et typisk eksempel på, hvordan hverdagsinteraktionen blandt projektets unge deltagere kan se ud i Messenger-grupper. Særligt karakteristisk er de korte beskeder (eller skriveture), brug af alternativ stavning og tegnsætning, slåfejl, skriftlige repræsentationer af udtale og udbrud, som alle er fænomener, vi vender tilbage til senere i artiklen. Endelig er korrespondancen her også karakteriseret ved brug af forkortelser. Her anvendes både Omg ('oh my God') og Wtf ('what 
the fuck'), der kan anskues som reaktioner på selve billedet eller den handling, at der bliver delt et børnebillede i gruppen. Begge forkortelser har vi observeret som hyppigt forekommende i de unges interaktioner på Facebook Messenger, og omg nævnes også i interviewene som et eksempel på en forkortelse, de unge bruger (se også Rotne 2009 og Hougaard 2004, 2014 for brug af lignende 'netkronymer' blandt unge). Dette uddrag viser, på linje med de unges metasproglige udsagn i uddrag 1, at brugen af hverdagsskriftsproglige forkortelser kan anskues som karakteristiske eller umarkerede i de unges kommunikative praksisser i private online kontekster. Begge uddrag belyser således en indeksikalsk forbindelse mellem brugen af hverdagssproglige forkortelser online og unge sprogbrugere.

Brugen af hverdagsskriftsproglige forkortelser er imidlertid ikke en normaliseret praksis blandt forældregenerationen. Tværtimod karakteriserer flere af forældrene sådanne forkortelser som et fænomen, der er associeret med de unges online sprogbrug. De genkender således den praksis og norm, som vi kan observere blandt de unge i uddrag 1 og 2 . Nogle forældre anskuer endvidere denne type forkortelser som ukorrekt sprogbrug og som noget, der på linje med stavefejl anskues som afvigende (og endda forstyrrende) sprogbrug. Dette ser vi i uddrag 3, hvor Lily, som er mor til Tina, beskriver sin egen online sprogbrug på følgende måde:

\section{Uddrag 3: "Ordene bliver skrevet fuldt ud"}

Interview. Deltagere: Lily (LIL) 51 år (Tinas mor). Interviewer: Astrid $(X A G)$

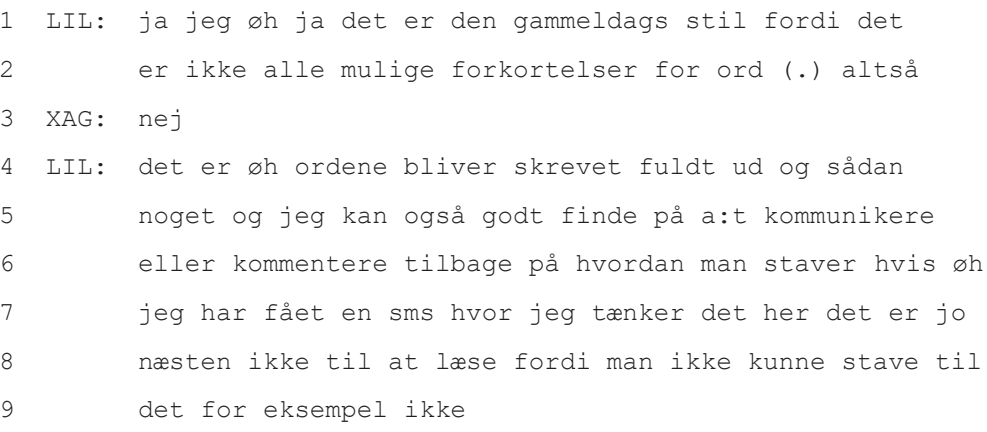


Lily karakteriserer her den måde, hun skriver på online, som en gammeldags stil (1. 1), der er karakteriseret ved, at ord ikke forkortes (1. 2) men skrives fuldt ud (1. 4). At hun refererer til forkortelserne som alle mulige (1. 2) indikerer, at hun her hentyder til hverdagsskriftsproglige forkortelser og ikke dem, der følger den standardortografiske norm. Ved at betegne sin egen stil som gammeldags fremstår denne i kontrast til den måde, de unge skriver på online. Endvidere sidestilles brugen af hverdagsskriftsproglige forkortelser her med meningsforstyrrende stavefejl (1. 7-9), hvorved Lilys gammeldags stil også forbindes med en korrekthedsnorm. En sådan orientering mod korrekthed er typisk forekommende blandt de voksne deltagere i undersøgelsen, hvilket vi skal se nærmere på i det følgende afsnit.

\subsection{Korrektur og tegnsatning}

Hvorvidt man læser korrektur og evt. retter tegnsætningen, inden man sender en besked, udgør en central forskel på tværs af de to generationer. Flere forældre giver nemlig udtryk for, at de ikke kun ynder at rette eller kommentere andres fejl, som Tinas mor gav udtryk for i uddrag 3, men også praktiserer at læse korrektur på egne beskeder, således at de fremstår sprogligt korrekte. De fleste deltagere fra den unge generation genkender i interviewene denne rettepraksis og orientering mod standardnormen blandt deres forældre. I uddrag 4 skal vi se, hvordan de unge ikke kun genkender denne praksis, men også eksplicit sætter den i kontrast til deres egne normer for korrektur og tegnsætning. Forud for dette uddrag spørger intervieweren ind til de unges korrekturpraksisser i forbindelse med online sprogbrug. Det får Maya til at fortælle følgende:

\section{Uddrag 4: "Du kan jo godt se hvad der skal stå"}

Interview. Deltagere: Adam (ADA) 17 àr, Lea (LEA) 15 àr, Maya (MAY) 16 àr og Eva (EVA) 16 àr. Interviewer: Andreas (XAS) 


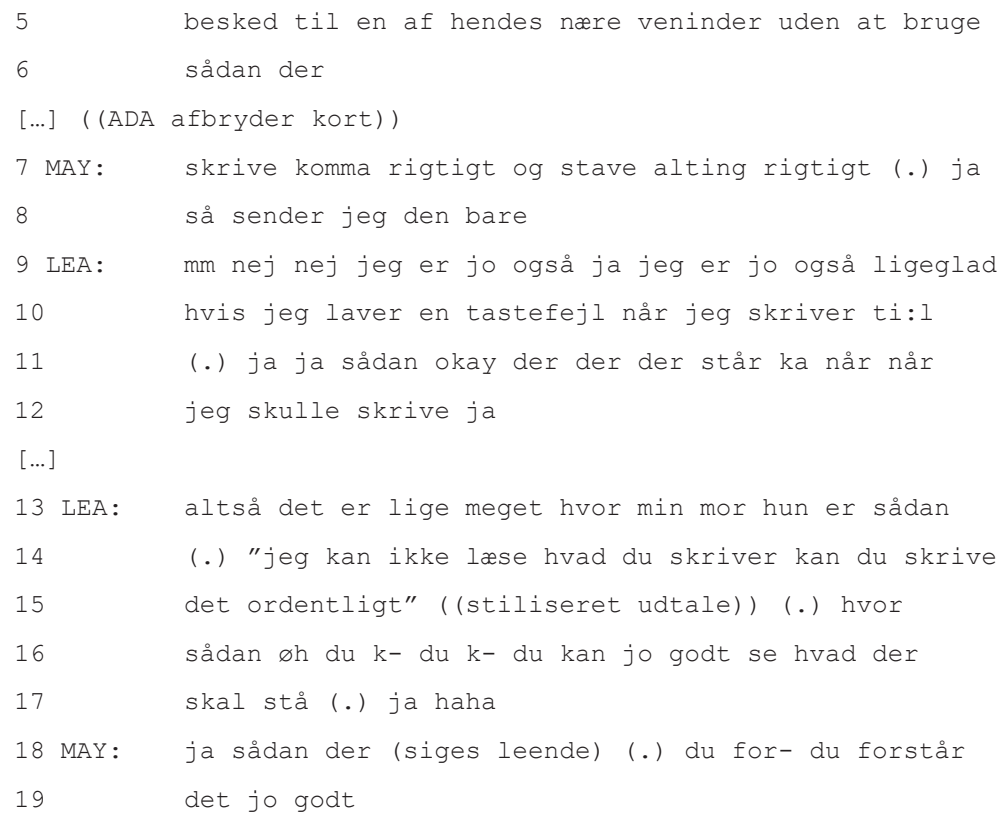

De unge i dette uddrag positionerer deres egen online hverdagssprogbrug i opposition til en sproglig korrekthedsnorm (1. 2-3 og 1. 9-10), når de skriver private beskeder til hinanden. Dette syn på korrekthed og korrektur i private online kontekster går igen hos flere af de unge deltagere i undersøgelsen, hvilket også fremgik af Messenger-korrespondancen i uddrag 2, der (ud fra et standardortografisk perspektiv) indeholdt flere tastefejl (hvem er set vs. hvem er det, Leaq vs. Lea), alternativ tegnsætning (...) og grammatiske afvigelser (udeladelse af kopulaverbet er i ytringen Ja det lea (se også Christensen et al. 2018)), som de unge ikke reagerede på.

I uddraget sætter de unge ydermere deres egen tilgang til korrekthed i kontrast til den måde, hvorpå deres forældre prioriterer at rette beskeder og sætte komma, når de skriver til hinanden (1. 4-8). At orientere sig mod sproglig korrekthed, når modtageren er en nær veninde, fremstår i denne forbindelse som en markeret handling for Maya, idet hun siger, at moren ikke engang (1. 4) kan skrive til en veninde uden at korrekturlæse. Mayas ytring kan ydermere tolkes som, at en skrivestil uden fokus på korrektur og tegnsætning for de unge er forbundet med 
en mere uformel og personlig stil, som anvendes i interaktionen med nære jævnaldrende. Lea tager ligeledes med en stiliseret mor-stemme (1. 14-15) afstand til den måde, hvorpå hendes mor orienterer sig mod korrekthed og stavefejl, når de skriver beskeder sammen. Denne afstandtagen markeres bl.a. ved at grine (linje 17) og nedtone stavefejls betydning for den intenderede mening (1. 18-19). Orientering mod korrekthed behandles altså i dette uddrag eksplicit som en generationsforskel, hvor forældrerettelser vurderes negativt. Det tyder således på, at forståelse (1. 18-19) går forud for korrekthed blandt de unge. Dette skal forstås således, at de unge nedvurderer rettelser af taste- og stavefejl, når de forekommer i situationer, hvor man godt [kan] se hvad der skal stå (1. 16-17), og hvor fejlen således ikke hindrer forståelsen af beskedens budskab. Endelig kan man argumentere for, at nedvurdering af sproglig korrekthed i dette uddrag udgør en praksis, som Lea og Maya kan anvende til at fremstille sig i opposition til deres forældre.

De unges holdninger til retstavning og tegnsætning bemærkes da også af forældrene. Dette så vi allerede et eksempel på i uddrag 3, hvor Tinas mor fortalte, hvorledes hun kommenterede sin datters stavefejl. I det følgende uddrag fortæller Mayas forældre, Sara og Brian, om deres oplevelse af Mayas online sprogbrug. Tidligere i interviewet har Sara givet udtryk for, at det er vigtigt for hende at bruge tid på at rette sine beskeder igennem, inden de sendes afsted. Dette stemmer godt overens med Mayas beskrivelse af sin mors forhold til korrekthed i det forrige uddrag. I uddrag 5 præsenterer intervieweren Sara og Brian for de unges opfattelse af, at de skriver anderledes end deres forældre:

\section{Uddrag 5: "Hun staver nærmest forkert med vilje"}

Interview. Deltagere: Sara (SAR) 33 år og Brian (BRI) 35 àr (Mayas foraldre). Interviewer: Andreas (XAS)

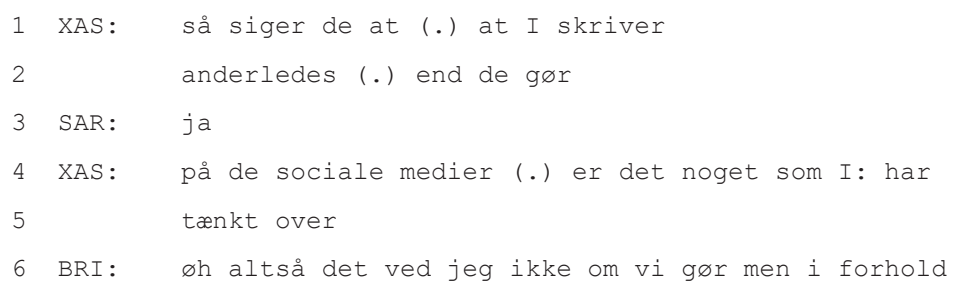




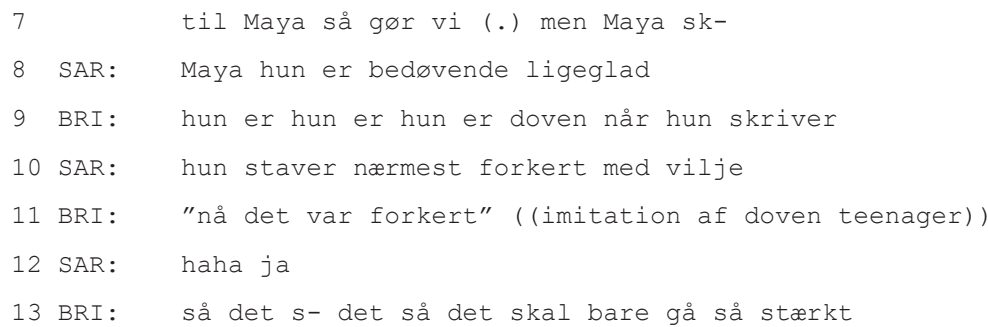

Både Brian og Sara genkender Mayas mindre korrekthedsorienterede skrivestil, som de karakteriserer som ligeglad (1. 8) og doven (1. 9), hvorved de implicit fremstiller sig selv som fornuftige voksne, der går op i retstavning. Forældrenes fremstilling af Mayas syn på korrekthed harmonerer med den måde, Maya fremstiller sig selv på i uddrag 4. Ifølge Brian er Mayas afslappede forhold til korrektur og korrekthed et udtryk for, at: det skal bare gå så starkt (1. 13) - en ytring, der kan tolkes som, at han genkender de unges præference for et højt kommunikativt flow, når de skriver sammen online, hvilket vi ser nærmere på i afsnit 5.4.

Når man retter blikket mod deltagernes faktiske online sproglige praksisser, er forskellene mellem de unge og deres forældres orienteringer mod korrekthed også til stede. Fra vores online etnografiske feltarbejde på de unges Facebook Messenger-tråde har vi observeret, hvordan de unge kun sjældent retter hinandens eller deres egen sprogbrug. I forlængelse heraf så vi også, hvordan forkortelser, slåfejl og alternativ stavning fremstod umarkeret i de unges online korrespondance i uddrag 2. I uddrag 6 skal vi se, hvordan de voksnes orientering mod korrektur og korrekthed kommer til udtryk, når de skriver med deres børn. Karen skriver her følgende til sin søn Mark: 
Uddrag 6 "Hvis"

Sms-korrespondance. Deltagere: Karen (Marks mor, 49 ar) og Mark (16 arr)

Tue, 18 Sep, 10.45

Hej Mark, hvordan går det?

Du kan tage et par panodiler,

hvid hovedet stadig gør ondt?

Hvis

Det gor ondt og skulle lige til at

sporge dig om jeg mătte, jeg

sidder og laver lidt lektier lige

nu

Det interessante i dette uddrag er Karens orientering mod den standardortografiske norm, hvilket kommer til udtryk i en selvinitieret rettelse, hvor hun retter tastefejlen hvid til hvis. At der her er tale om en tastefejl er sandsynligt, idet $s$ og $d$ er naboer på telefonens tastatur. HyttelSørensen \& Stæhr (2014) og Stæhr (2016a) peger på, at denne type rettelser blandt unge på Facebook enten kan fungere som en metasproglig strategi for at markere, at man kender til eller behersker standardortografien eller som en måde at udføre face-work på (Goffman 1955) i den forstand, at en selvinitieret kan beskytte en mod at blive konstrueret som en dårlig staver. I dette tilfælde er det nærliggende at tolke Karens rettelse som en strategi til at markere, at hun udmærket behersker den ortografiske standard, hvilket ydermere understøttes af den efterfølgende emoji, som kan tolkes som en måde at signalere over for Mark, at hendes tastefejl var fjollet. Derudover kan man se, at Karen i resten af beskeden anvender en standard(nær) tegnsætning og skriver i henhold til retskrivningsnormen, hvilket tyder på at retskrivning også i denne hverdagsskriftsproglige kontekst bliver prioriteret hos Karen. Udover at opretholdelse af den ortografiske standard kan være forbundet med høj status (Stæhr 2016a), kan man også argumentere for, at der er et sprogsocialiserende eller pædagogisk element på spil her, i den forstand 
at Karen fremstår som et sprogligt forbillede for sin søn i kraft af hendes implicitte og eksplicitte orientering mod den ortografiske standard.

På baggrund af analyserne i dette afsnit (og vores online etnografiske viden generelt), tyder det på, at forældrene i højere grad er orienterede mod standardnormen end de unge, når det gælder sprogbrug $\mathrm{i}$ private online kontekster. Ydermere peger analyserne på, at de unge nedprioriterer korrektur og tegnsætning i beskeder til nære jævnaldrende. Hvorvidt dette mønster også gør sig gældende i offentlige eller semi-offentlige online kontekster, såsom Instagram og Facebook, har vi ikke undersøgt systematisk. Dog har vi bemærket, at de unge i deres opslag på Instagram ser ud til at orientere sig mere mod den standardortografiske norm. Endvidere giver de udtryk for, at det er vigtigt at skrive korrekt i fødselsdagshilsner på Facebook, som alle kan se: "sådan noget fødselsdagshilsner skal der nærmest ikke være nogen stavefejl" (Lea, gruppeinterview) (se også Hansen 2021:62). Til trods for dette viser vores analyser af de unges og deres forældres normative orienteringer, at både op- og nedvurdering af den standardortografiske norm udgør et centralt element i de igangværende registergørelsesprocesser, som ligger til grund for etableringen af henholdsvis online 'ungdoms-' og 'voksenstile'.

\subsection{Emojibrug}

Forskelle i emojibrug er et udbredt emne blandt både de unge og voksne deltagere i de interviews, vi har foretaget med dem. I dette afsnit undersøger vi, hvordan emojibrug bliver tilskrevet forskellige værdier og funktioner blandt de unge og voksne deltagere, og hvorvidt sådanne markører overhovedet opleves som nødvendige for at forstå konteksten af det skrevne i private online interaktioner. Overordnet set bliver emojibrug fremstillet som et forældre- eller børnefænomen og som noget, de unge kun sjældent bruger i deres private online korrespondancer. Det skal vi se et eksempel på i uddrag 7, hvor Saarah siger:

\section{Uddrag 7: "Hvor gammel er du"}

Interview. Deltagere: Sandra (SAN) 16 år, Mike (MIK) 17 år, Aayan (AAY) 16 àr og Saarah (SAA) 16 àr. Interviewer: Astrid (XAG) 


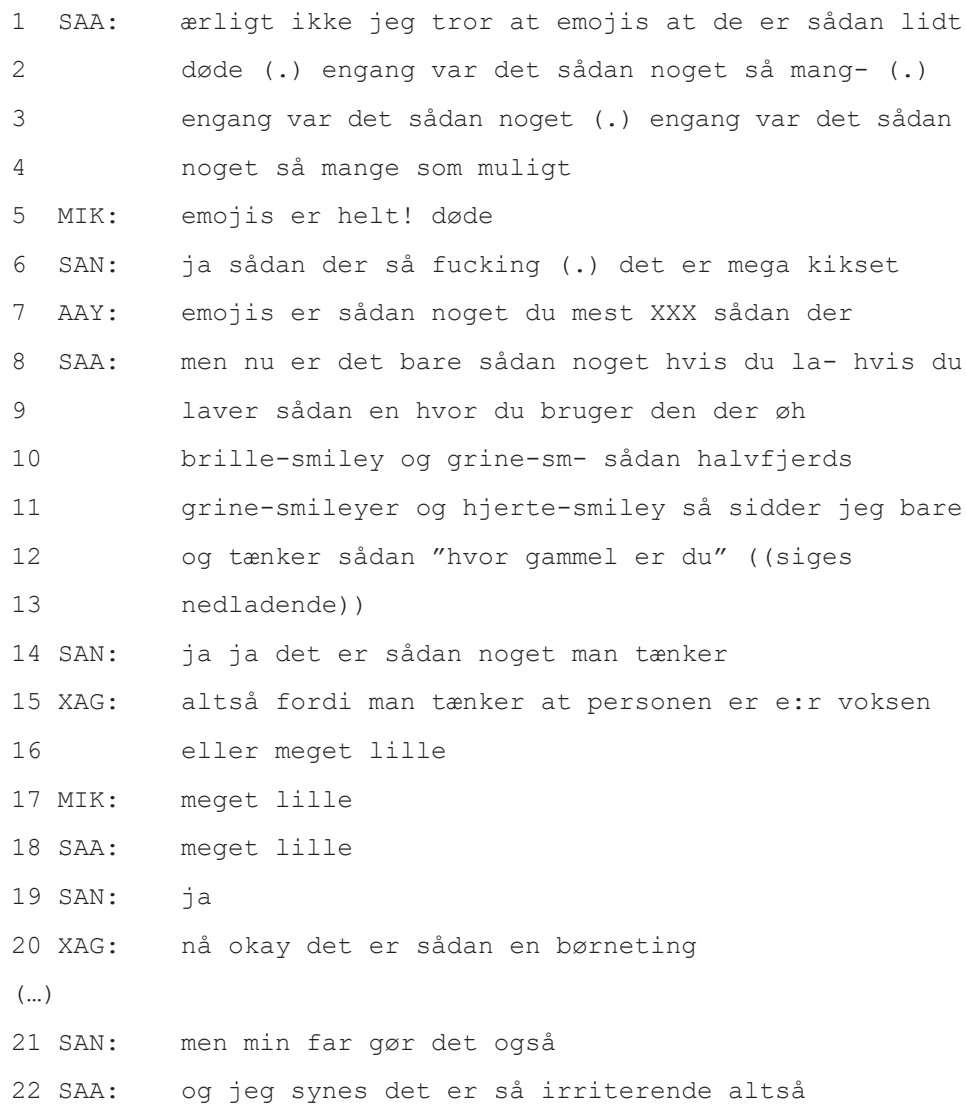

Emojibrug bliver her nedvurderet blandt de unge (1. 5, 6 og 22) og bliver fremstillet som en sproglig praksis, der er forbeholdt henholdsvis børn (1. 17-18) og forældre (1. 21). Således bliver emojibrug eksplicit fremhævet som en sproglig aldersmarkør (1. 11-12). De unge peger her på, hvordan deres egen emojibrug har været underlagt en sproglig forandringsproces, idet Saarah bl.a. fremhæver, hvordan hun selv brugte flere emojis, da hun var yngre (1. 3). Dette er et hyppigt forekommende narrativ blandt mange af de unge, vi har interviewet. Ydermere giver næsten alle de unge deltagere udtryk for, at forældregenerationen (og voksne i al almindelighed) er flittige emojibrugere, hvilket vi så, var tilfældet i det citat, vi indledte artiklen med. Forældregenerationen fremstilles imidlertid ikke kun som flittige emojibrugere, men også 
som overforbrugere af emojis. En af de unge deltagere, Lea, siger eksempelvis om sin far "der var fire emojis i de tre linjer han sendte" (Lea, gruppeinterview). Endelig fremstår emojibrug i dette uddrag som en sproglig praksis, de unge kan bruge til at positionere sig i opposition til både børn og voksne.

Det er ikke kun i de unges øjne, at emojis opfattes som et forældrefænomen eller et træk forbundet med voksnes online sprogbrug. Uddrag 8 illustrerer, hvordan de voksne deltagere også anskuer emojibrug som et forældrefænomen. Uddraget er fra en media go-along-samtale, hvor feltarbejderen og Karen, gennemgår hendes sms-beskeder med sønnen Mark. Feltarbejderen har bemærket, at Karen bruger væsentligt flere emojis sammenlignet med hendes søn i deres sms-korrespondance. Derfor spørger han:

Uddrag 8: "Det er nok mere mig, det bruger han ikke" Media go-along samtale. Deltagere: Karen (KAR) (Marks mor, 49 år). Interviewer: Andreas (XAS)

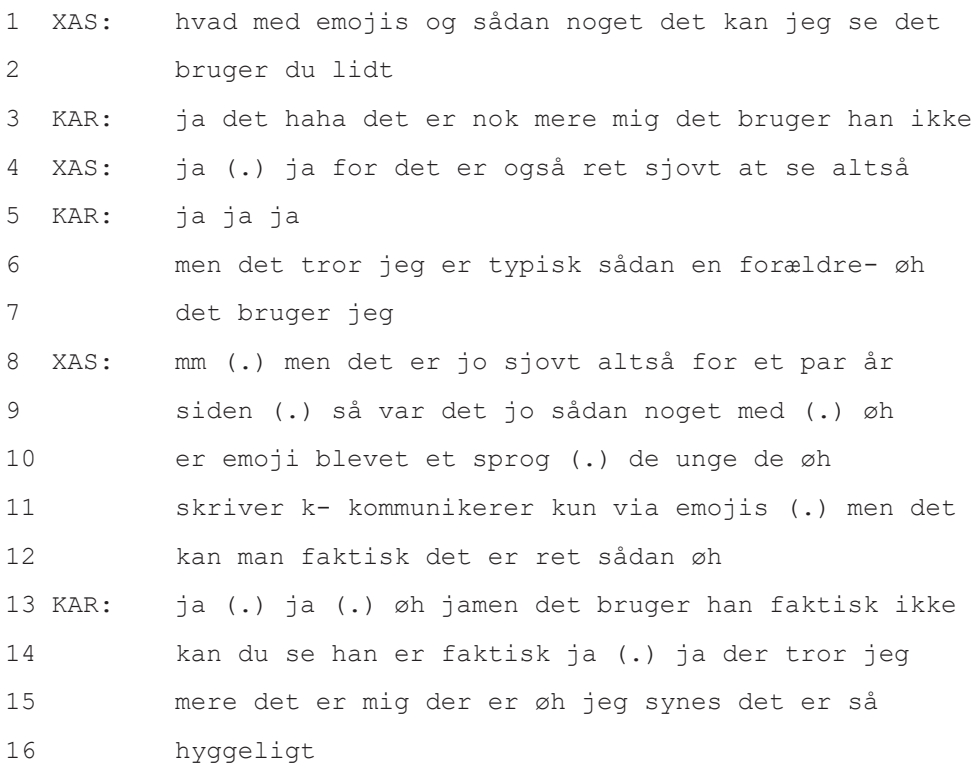


Ud over at være et semiotisk træk, som hun selv bruger, karakteriserer Karen her emojis som et typisk forældretræk (1. 6). Hendes selvafbrydelse kan dog tolkes som en indikation på, at hun er forbeholden overfor at ytre sig på vegne af en hel generation. Da hun bliver bedt om at forholde sig til den stereotype opfattelse, at unge skulle være flittige brugere af emojis (1. 8-11), afviser hun dette og henviser i denne sammenhæng til korrespondancen på skærmen (1. 13-14), hvor man kan se, at hendes søn ikke bruger emojis. I denne forbindelse skal det nævnes, at vi fra vores online etnografi ved, at Mark nogle gange bruger emojis, når han skriver online med sin mor. Dog stemmer det overordnede billede af, at Karen bruger flere emojis end Mark, imidlertid godt overens med vores observationer af deres sms-korrespondancer. Endelig er det interessant at se, hvordan emojibrug i dette uddrag associeres med positive indeksikalske værdier (såsom hygge), der står i kontrast til de unges nedvurdering af emojibrug i uddrag 7 .

Når man ser på deltagernes sproglige online praksisser, stemmer dette godt overens med deres metasproglige refleksioner, hvor forældrene fremhæves som den generation, der bruger emojis mest. Et eksempel på dette er uddrag 9, hvor en gruppe veninder i 40'erne skriver sammen for at arrangere julehygge hjemme hos Charlotte, inden de skal i biografen med deres døtre. 
Uddrag 9: "Kære alle"

Messenger-korrespondance. Deltagere: Charlotte, Mette, Pia og Lisa

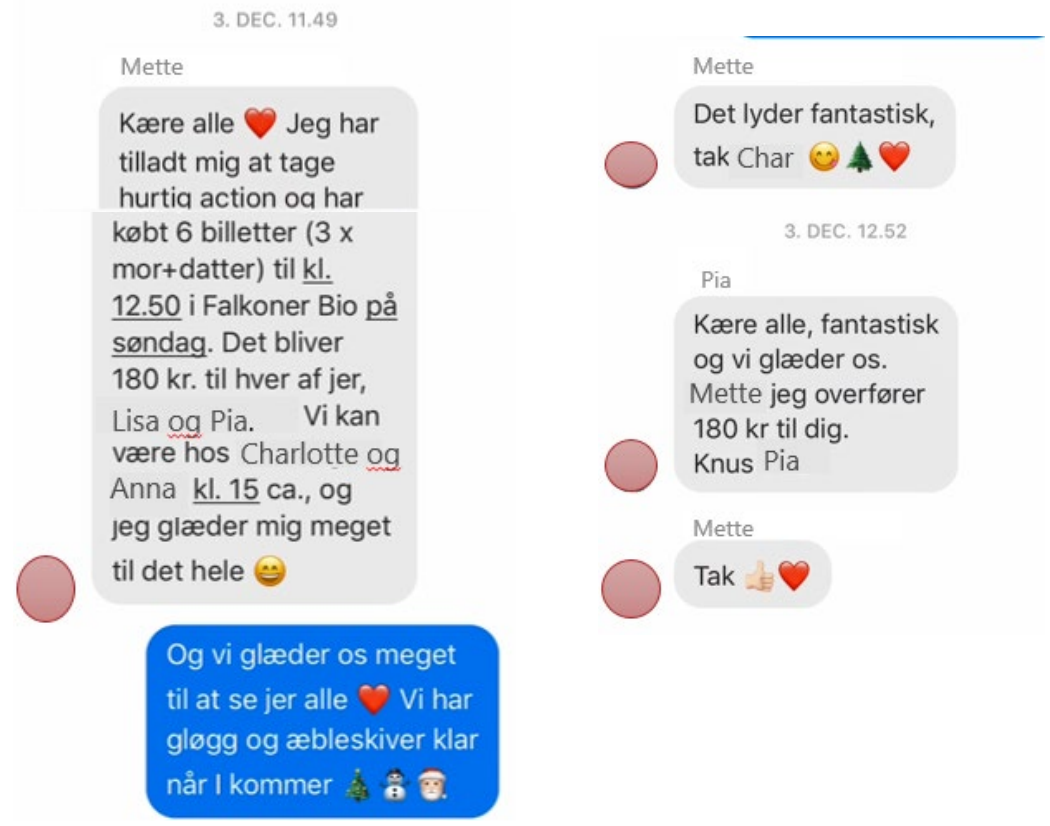

Dette uddrag er på mange måder repræsentativt for den måde, forældregenerationen i projektet bruger emojis på. I uddraget kan vi eksempelvis se, hvordan der næsten forekommer emojis i hver skrivetur. Hvis man sætter denne hyppige brug i relation til de unges måde at skrive på (som er eksemplificeret i uddrag 2), er det almindeligt, at der i en privat online interaktion mellem de unge forekommer flere skriveture, hvor der ikke anvendes emojis. Dette er ikke ensbetydende med, at de unge slet ikke anvender emojis, men på baggrund af vores online etnografi i Messenger-grupperne finder vi, at der ofte kan være langt mellem emojierne, og at de ofte kun sender en eller to emojis ad gangen. I dette uddrag er der flere eksempler på skriveture, hvor der anvendes flere emojis efter hinanden. Dette er tilfældet i Charlottes besked, hvor et juletræ, en snemand og en julemand sættes lige efter hinanden. Her er det hver enkelt emojis ikoniske betydning (indsat i en betydningskæde af andre emojis), der danner grundlaget for, hvordan ytringen skal forstås. Her 
kan man argumentere for, at kæden af emojis, sammen med indholdet (gløgg og æbleskiver) og afsendelsestidspunktet (d. 3. december), skal indeksere julestemning eller -hygge. Det samme gør sig gældende for Mettes efterfølgende brug af tre efter hinanden stillede emojis (et ansigt med tungen ud ad munden, et grantræ og et hjerte), som kan tolkes som en understregelse af, at Mette ser frem til julehygge. Under vores online etnografi har vi observeret, at denne type sammensætning af emojis efter hinanden er mindre hyppigt forekommende hos de unge end hos de voksne. Når denne type af emojisammensætning forekommer hos de unge, er det ofte i form af ansigts-emojis, der sættes efter hinanden. I analysen af de voksnes emojibrug i dette uddrag er det vigtigt at anskue (og forstå) deres praksis i relation til en række andre sproglige træk, der ligeledes forbindes med voksen- eller forældresprog online. For eksempel består interaktionen af en række sproglige og kommunikative træk, som både de unge og voksne deltagere forbinder med en voksensproglig praksis: Det gælder den brev- eller e-maillignende åbner Kare (besked 1 og 5), (en tilstræbt) korrekt tegnsætning, konsekvent brug af fuldt udskrevne former i stedet for forkortelser og lange beskedture (se også afsnit 6.4).

På baggrund af analyserne i dette afsnit ser vi, hvordan emojibrug bliver registergjort som en semiotisk ressource associeret med en online voksen- eller forældrestil. Ydermere peger de unge deltagere på en sproglig forandringsproces, når de italesætter, hvordan de er blevet mere selektive i forhold til, hvornår og hvordan de bruger emojis, end de var tidligere. Flere af de unge deltagere giver imidlertid også udtryk for, at de sagtens kan forstå hinanden uden at sætte emojis, men understreger samtidig, at emojis er anvendelige, hvis man vil være meget eksplicit om, hvordan noget skal forstås. Hvis man ser på interaktionen mellem de unge i uddrag 2, hvor der ikke anvendes emojis, er det tydeligt, at de unge har kendskab og adgang til andre sproglige ressourcer, der på linje med emojis kan fungere som kontekstualiseringsmarkører, fx interjektionaler i form af skriftlige repræsentationer af latter (ahhahahahhahahah) eller andre udbrud (nurgh) samt hverdagsskriftsproglige forkortelser (eller netkronymer) som omg og $w t f$. Det interessante i denne forbindelse er, at disse træks betydningspotentialer i princippet ville 
kunne udtrykkes med forskellige emojis. En yderligere forklaring på, at de unge i mindre grad anvender emojis til sådan kontekstualisering, er, at de unge ikke "gider [...] at man skal til at ændre tastatur for at gå ind og vælge og så sidde og kigge dem ((emojierne)) igennem for hvad der passer til hvad man mener" (Laura, gruppeinterview). Ud over det besværlige i at vælge tastatur og de korrekte emojis er der ydermere et tidsaspekt forbundet med dette, idet Laura siger "det har jeg ikke tid til". Der er således ikke noget, der tyder på, at de unge ikke behersker eller har kompetencen til at anvende emojis, idet vi kan observere hvordan de (hyppigere) anvender emojis på eksempelvis Instagram, og at de i interviews redegør for, hvordan emojis kan have forskellige kontekstualiserende betydninger ( $\mathrm{fx}$ understregning af ironi). Fravalget af emojis i private online kontekster kan snarere forklares med, at de unge anskuer dem dels som kiksede (uddrag 7) og dels som unødvendige og tidskrævende i kontekster, hvor der bl.a. er fokus på at opretholde et kommunikativt flow. Netop det, at kommunikativt flow og korte svartider udgør et centralt aspekt ved de unges online interaktion, skal vi se nærmere på i det næste afsnit.

\subsection{Beskedlangde og kommunikativt flow}

Både de unge og voksne deltagere giver udtryk for, at unge generelt skriver kortere beskeder end forældrene. Dette skal vi se nærmere på i uddrag 10, hvor intervieweren spørger ind til, hvad der karakteriserer unges kommunikation på de sociale medier:

\section{Uddrag 10: "Det skal være korte beskeder"} Interview. Deltagere: Andrea (AND) 16 àr, Heidi (HEI) 16 àr og Alex (ALE) 16 àr. Interviewer: Andreas (XAS)

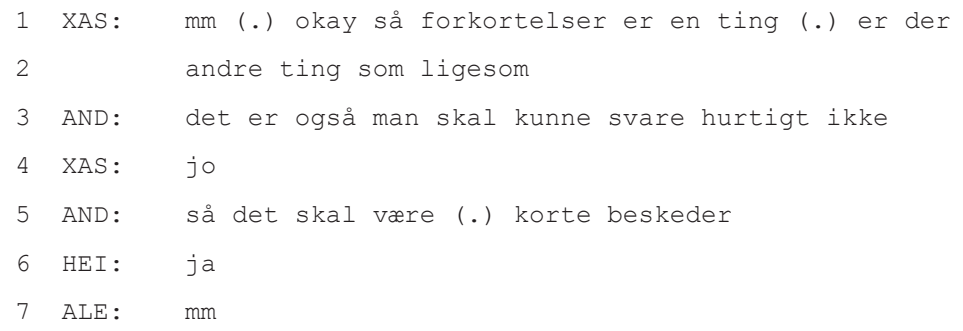




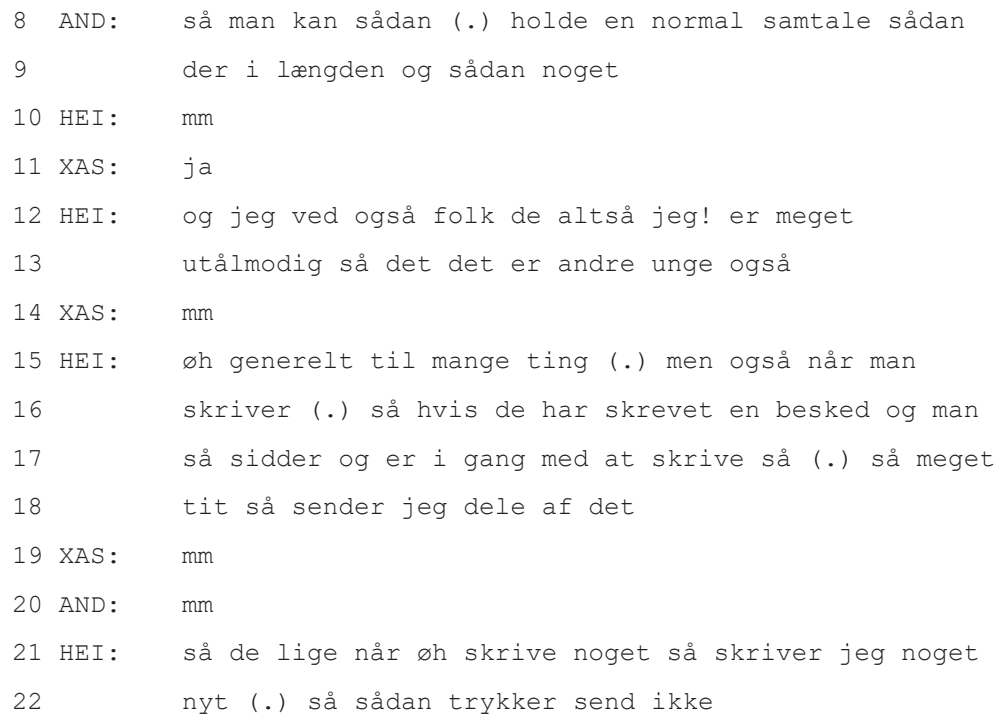

Her italesættes hurtige svartider som en central norm for unges online kommunikation (1. 3). Motivationen for korte beskeder er således her at tage hensyn til andre (jævnaldrende) samtalepartnere, der ligesom dem selv er for utålmodige til at læse lange beskeder (1. 1213). På baggrund af dette kan man argumentere for, at præferencen for korte beskeder er motiveret af at kunne svare hurtigt og således ikke skal anskues som økonomisering motiveret af tegnbegrænsning. I forlængelse af dette efterlever mange unge også en praksis, hvor de deler længere beskeder op i mindre ture (l. 17-18). På den måde kan de sende større mængder information, mens de stadig kan overholde kravet om korte skriveture og svartider og således opretholde et ideal om et kommunikativt flow, som man kender fra talesproglige praksisser (1. 8 en normal samtale) - et ideal, som mange af de unge genkender i de interviews, vi har foretaget med dem.

I det følgende skal vi se, hvordan forældregenerationen forholder sig til det at skrive lange og korte beskeder. På baggrund af vores interviews med forældregenerationen er det tydeligt, at mange forældre genkender de unges 'korte' beskeder, hvilket også kommer til udtryk i uddrag 11 . I uddraget møder vi Christina, som er mor til Lea. Konteksten for uddraget er, at Christina netop har vist feltarbejderen en række sms-korrespondancer med henholdsvis sin egen mor og datter. Her kan man se 
et tydeligt mønster, der viser, at korrespondancerne med datteren består af kortere skriveture, mens skriveturene er længere, når hun skriver med sin mor. Derfor spørger feltarbejderen:

Uddrag 11: "Hun responderer jo ikke på det altså” Media go-along-samtale. Deltagere: Christina (CHR) (Leas mor, 49 år). Interviewer: Andreas (XAS)

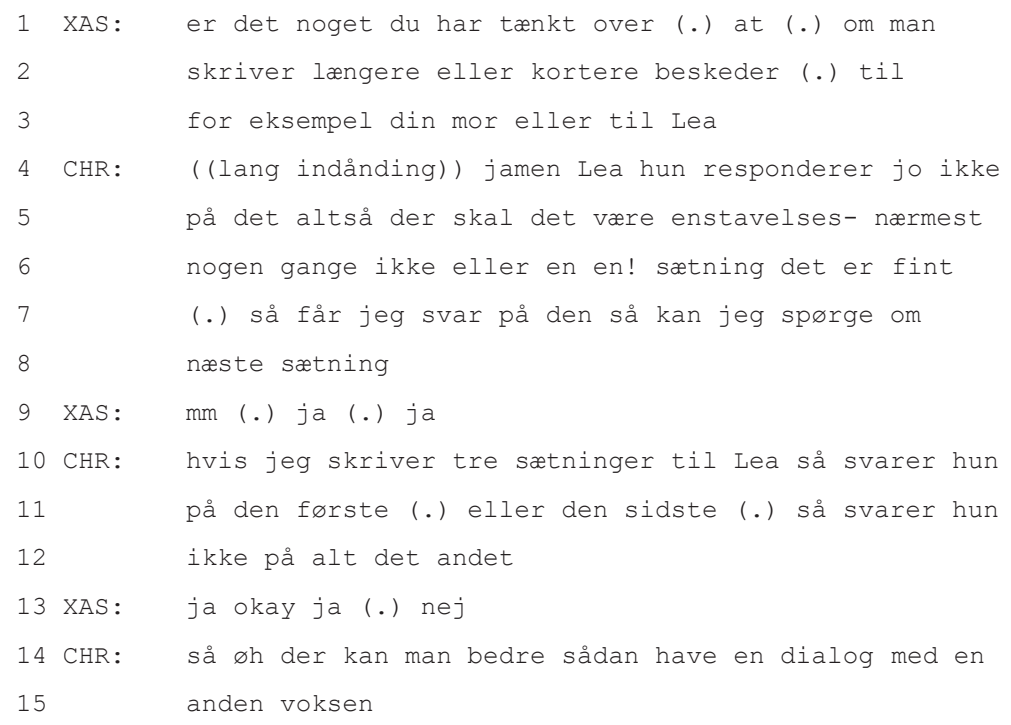

Christina genkender de unges praksis med at sende korte beskeder, og ifølge Cristina indvirker dette på, hvor lange beskeder hun kan skrive til sin datter. I modsætning til de unge, der ser de korte beskeder som et middel til at føre en normal samtale med et højt flow (uddrag 10, 1. 8), giver Christina her udtryk for, at de korte beskeder er hæmmende og står i vejen for en dialog (1. 14), som man kan have med en anden voksen (1. 14-15). Uddrag 10 og 11 peger på, at de unge og deres forældre har forskellige opfattelser af, hvad der karakteriserer en online dialog eller en normal samtale online (uddrag 10, 1. 8), og at dette bl.a. relateres til en norm om henholdsvis lange eller korte beskeder, som er hyppigt italesat blandt både de unge og deres forældre. Ydermere har vi generelt også observeret, at der er forskel på beskedlængden i de unges private 
Messenger-grupper, når man sammenligner med de voksnes beskeder til jævnaldrende.

De unge og forældrenes præferencer for henholdsvis korte og lange beskeder skal ses i relation til de andre sproglige generationsforskelle, vi har peget på i vores analyser. Blandt de unge er korte beskeder med et højt kommunikativt flow normen og hænger bl.a. sammen med normerne for at bruge forkortelser (afsnit 5.1), ikke at bruge tid på korrekturlæsning (afsnit 5.2) og det, at de er mere selektive omkring, hvornår de bruger tid på at skifte tastatur og vælge emojis (afsnit 5.3). Omvendt er det normen blandt forældrene at have præference for længere beskeder, at bruge tid på korrekturlæsning, bruge emojis og at skrive ordene fuldt ud. Tilsammen udgør disse forskellige sproglige praksisser og normative orienteringer 'byggestenene' i de igangværende registergørelsesprocesser af online stile eller registre, der kan associeres med henholdsvis voksnes og unges online sprogbrug. Ydermere er det på baggrund af vores analyser også tydeligt, at både unge og de voksne genkender (og har en holdning til) hinandens normer for sprogbrug og sproglige online praksisser. Indtil nu har vi fokuseret på, hvordan de unge og deres forældres adskiller sig sprogligt og kommunikativt fra hinanden. I det følgende afsnit ser vi nærmere på, hvordan begge generationer ytrer et behov for nogle gange at tilpasse sig hinanden sprogligt, og at de til dette formål har forskellige strategier til rådighed.

\section{SPROGLIG TILPASNING PÅ TVARS AF GENERATIONER}

De to generationers kendskab til hinanden og hinandens normer for sprogbrug viser sig at være en nyttig ressource, når de skal tilpasse sig hinanden. Ved netop at skrue op (eller ned) for nogle af de sproglige og kommunikative træk, den anden generation bruger, kan de nemlig fremstå mere imødekommende over for hinanden, når de kommunikerer online. I dette afsnit vil vi primært fokusere på, hvordan de unge og voksne sprogbrugere tilpasser sig hinanden i forhold til emojibrug og beskedlængde. I uddrag 12 skal vi se, hvordan de unge giver udtryk for, hvordan de kan skrue op for brugen af emojis for at imødekomme deres forældres kommunikative stil: 
det interessant, at denne hjerte-emoji (og alle andre emojis for den sags skyld) er stort set fraværende i hendes sms-korrespondancer med sin far. Dette kan skyldes, at faren med få undtagelser heller ikke bruger emojis i sine beskeder til Eva. Det tyder således på, at Eva konvergerer sin sproglige stil forskelligt alt afhængigt af om hun skriver med sin mor eller far. I dette uddrag er det imidlertid også interessant at se, hvordan de unge også konvergerer deres emojibrug i mere formelle situationer eksempelvis når de skriver med deres chef (1. 12). Motivationen for at konvergere sprogligt i denne type korrespondancer er, at man vil fremstå venlig (1. 14), hvorfor man kan argumentere for, at emojibrug kan tilskrives en formel høflighedsfunktion i sådanne situationer. Ydermere stemmer motivationen for sproglig tilpasning i dette tilfælde overens med den antagelse, at sprogbrugere akkommoderer dels for at opnå social anerkendelse hos andre samtalepartnere og dels for at kommunikationen foregår så uproblematisk og effektivt som muligt (Giles et al. 1991:18-20).

I de følgende to uddrag skal vi se nærmere på motivationen for, at de unge kan vælge at konvergere deres emojibrug, når de skriver med deres forældre. I uddrag 13 bliver de unge spurgt, om de bruger emojis med deres forældre:

\section{Uddrag 13: "Hvis man lige skal fedte lidt"}

Interview. Deltagere: Jamir (JAM) 16 ar, Molly (MOL) 16 ar og Stephanie (STE) 16 àr. Interviewer: Andreas (XAS).

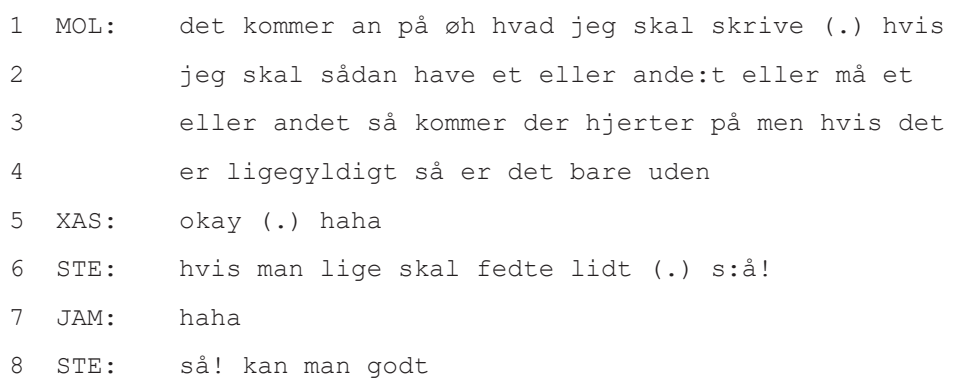


De unge kan altså tilpasse deres emojibrug, hvis de ønsker at opnå noget socialt, eksempelvis hvis de vil øge deres chancer for at få tilladelse til noget eller få noget af deres forældre (1. 1-2). Stephanie uddyber ydermere, hvordan man kan indsætte emojis i beskeder, hvis man lige skal fedte lidt (l. 6 og 8). I sådanne tilfælde kan emojibrug også anskues som en nedtoningsstrategi i face-truende aktiviteter, hvor man risikerer at få afslag på en anmodning. På denne måde kan de unge rent sprogligt imødekomme deres forældre ved at anvende flere emojis, end de normalt gør. I denne sammenhæng handler det selvfølgelig ikke kun om at anvende emojis, men også om at anvende de 'rigtige' emojis i forhold til det, man gerne vil opnå - i Mollys tilfælde er der tale om hjerte-emojis (1. 3). I uddrag 14 skal vi se, hvordan Maya anvender emojis i en situation, hvor hun skal bede sin bonusfar om en tjeneste:

Uddrag 14: "Hej søde Brian"

Sms-korrespondance. Deltagere: Maya (16 ar) og Brian (35 arr) (Mayas stedfar)

tir. 16. okt. 23.24

Hej søde Brian vil du hente

min cykel efter arbejde i

morgen?

\section{Hvad făr jeg for det..? (e) (4)}

I denne sms-korrespondance ser vi et eksempel på, hvordan emojis kan anvendes strategisk af de unge til at opnå det, de gerne vil i interaktionen med deres forældre. Brugen af emojis i dette uddrag fremstår nemlig alt andet end tilfældig, idet den står i tydelig kontrast til den mere begrænsede emojibrug, vi ellers har observeret i mange af Mayas beskeder. Kombinationen af emojierne og det kærlige adjektiv søde (som heller ikke er noget, hun normalt indleder sine beskeder med) tyder på, at Maya forsøger at virke særligt imødekommende over for Brian. Dette kan ses som en kommunikativ strategi, der gør, at han får sværere ved at afslå hendes anmodning. Brians respons, hvor han spørger, hvad han 
får til gengæld (bemærk dollar-emojien), kan tolkes som, at han godt er klar over, at Maya søger at opnå noget bestemt med sin konvergerende og strategiske sprogbrug. At dette er tilfældet, understøttes yderligere af Mayas forældres metasproglige kommentarer til denne besked i en media go-along-samtale. Med henvisning til beskeden siger Sara grinende: "Så kommer der lige hjerter på", hvilket understøtter vores tolkning af, at beskeden dels fremstår konvergerende, og dels at hendes emojibrug fremstår markeret i forhold til den måde, hun normalt skriver på. Sara fortsætter: "Så ved hun godt lige hvor hun skal", men afbrydes af Brian, der supplerer "der skal lige trykkes lidt der". Således fremstår det som om, de genkender hendes brug af emojis som en strategisk handling, hun kan anvende til at opnå det, hun gerne vil.

Det er imidlertid ikke kun de unge deltagere, der ytrer et behov for at tilpasse deres sproglige stil til forældrene. Også blandt forældrene italesættes emojis som et kommunikativt træk, man kan tilpasse for at imødekomme ens børn. Her fortæller Sigrid, hvordan hun tilpasser sin emojibrug forskelligt, alt efter hvem af hendes to børn, hun skriver med. Hun forklarer dette med, at børnene har to forskellige stilarter, idet hun siger:

\section{Uddrag 15: "To forskellige stilarter"}

Interview. Deltagere: Sigrid (SIG) 56 ar (Luna og Jacobs mor). Interviewer: Thomas $(X T N)$.

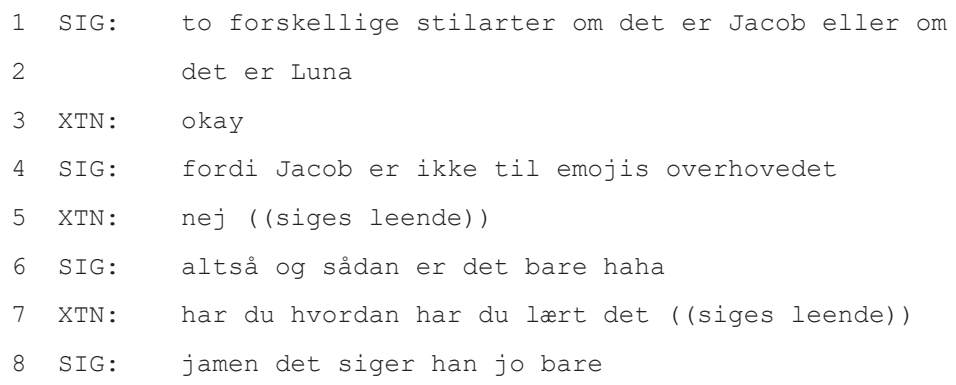


Her ser vi, hvordan forældrene også kan konvergere deres emojibrug, når de interagerer med deres børn. Ligesom de unge, der kunne bruge emojis som led i en tilpasningsstrategi, kan forældrene altså modsat helt undlade at skrive emojis som led $\mathrm{i}$ en lignende strategi. Ydermere er det interessant, at Sigrid giver udtryk for, at hun akkommoderer forskelligt alt efter, om hun skriver til sin søn eller datter, idet de skriver på forskellige måder (se Hansen 2021 for en uddybet analyse af morens emojipraksis med børnene). Det er imidlertid ikke kun gennem emojibrug, at forældrene kan konvergere deres sproglige stil. En anden tilpasningsstrategi, som flere forældre beskriver, er at sende korte beskeder. Eksempelvis fremhæver Monika ( 47 år), som er mor til en af de unge deltagere, hvordan hun skriver korte beskeder til sine børn: "du kan se mine er bliver heller ikke lange [...] og det er jo et eller andet med jeg tænker øh jeg prøver at tilpasse mig noget” (Media go-along-samtale med Monika). En lignende overvejelse omkring beskedlænge så vi også italesat blandt en af de andre forældre i uddrag 11. Således bliver det at producere korte skriveture en kommunikativ ressource til tilpasning på linje med den måde, hvorpå både unge og voksne kan konvergere deres emojibrug.

\section{KONKLUSION}

Vi har i denne artikel undersøgt sproglige generationsforskelle blandt en gruppe unge og deres forældre med særligt fokus på deres sprogbrug i private online kontekster. Vores analyser viser, at de unge og de voksne deltageres online sprogbrug adskiller sig fra hinanden. Overordnet set kan vi konkludere, at de unge og deres forældre har forskellige normer for digitalt medieret sprogbrug, når man fokuserer på deres brug af hverdagssproglige forkortelser, korrektur- og tegnsætningspraksisser, emojibrug og beskedlænge. Mere specifikt har vi vist, hvordan de unge italesætter en generel forventning om, at kommunikationen på de sociale medier skal have et højt kommunikativt flow. De orienterer sig således mod en stil, hvor idealet er at skrive hurtigt og på den måde fremstå nærværende. Dette opnås, ifølge de unge deltagere, ved at skrive korte beskeder, bruge hverdagssproglige forkortelser og begrænse det, de anskuer som tidskrævende kommunikative processer: $\mathrm{fx}$ at rette/korrekturlæse deres beskeder, sætte komma samt finde og sende pas- 
sende emojis. Hvad angår emojis, understreger de unge i imidlertid, at disse kan have vigtige kontekstualiserende funktioner, hvis man eksempelvis ønsker at være meget eksplicit om, hvordan det skrevne skal forstås. I modsætning til de unge viser vores analyser, hvordan de voksne deltagere beskriver korrekt og fyldestgørende online kommunikation som deres normative ideal, hvilket resulterer i en kommunikationskultur, der indebærer at sende længere beskeder, der er korrekturlæste og akkompagneret af emojis.

På baggrund af de sproglige og kommunikative generationsforskelle, vi har peget på i vores analyser, kan man argumentere for, at de unge og deres forældre har forskellige forventninger til og forståelser af, hvad der karakteriserer selve kommunikationssituationen, når de interagerer i private online kontekster på de sociale medier. I forlængelse heraf kan vi også konkludere, at deres kommunikative præferencer har indflydelse på, hvilken status den ortografiske standard tillægges. For forældregenerationen er overholdelse af den ortografiske standard associeret med høj status, hvilket manifesterer sig i deres (for nogle omhyggelige) rette-praksisser samt fokus på korrekthed og tegnsætning i deres egne og deres børns beskeder. Til sammenligning har vi vist, hvordan de unge ikke tillægger den ortografiske standard eller korrekt tegnsætning den samme betydning, som deres forældre. På baggrund af de unges (og deres forældres) metasproglige refleksioner kan vi konkludere, at de unge ikke prioriterer korrekt stavning, korrekturlæsning og tegnsætning i private interaktioner med jævnaldrende (se Hansen 2021 for en mere nuanceret gennemgang af standardens status blandt unge i henholdsvis semi-offentlige og private kontekster).

En central indsigt fra vores analyser er, at de unge og deres forældre ikke kun er refleksive omkring deres egne normer for sprogbrug. De er også opmærksomme på, hvordan andre generationer bruger sprog anderledes end dem selv, når de kommunikerer online. I analyserne af sproglig tilpasning peger vi på, at fordi deltagerne er opmærksomme på de generationelle forskelle, kan de anvende denne viden til at tilpasse sig andre generationers sprogbrug, hvilket vi har vist, at de også nogle gange gør i praksis. Vi har illustreret, at både de unge og deres forældre ytrer et behov for at tilpasse deres sprogbrug til hinanden. I vores analyser viser vi, hvordan de gør dette for at opnå bestemte sociale formål: 
fx at fremstå mere imødekommende eller opnå noget socialt samt at sørge for, at kommunikationen foregår så uproblematisk som muligt. Til disse formål, finder vi, at deltagerne har flere tilpasningsstrategier. De unge kan eksempelvis bruge emojis strategisk, og nogle går mere op i korrektur, når de kommunikerer med deres forældre, mens nogle af forældrene for eksempel sender kortere beskeder og færre emojis, når de skal tilpasse sig deres børn.

I store træk stemmer vores undersøgelse af sproglige generationsforskelle overens med en stereotyp opfattelse af, at unge er innovative og kreative sprogbrugere, mens voksne fremstår mere konservative. Vi fandt imidlertid én undtagelse - nemlig brugen af emojis, der på tværs af begge generationer bliver registergjort som et forældre- eller voksenfænomen. Dette resultat er særligt interessant, idet det bryder med en stereotyp opfattelse af, at emojibrug er et sprogligt fænomen, der er associeret med unges online sproglige praksisser og kreative online sprogbrug generelt. Vores undersøgelse peger således på et muligt skift i emojiernes status fra et ungdoms- til voksenfænomen, hvilket tyder på, at emojibrug er underlagt en igangværende sproglig forandringsproces (se uddrag 7), der er kendetegnet ved, at emojis bevæger sig fra at være et kreativt ungdomstræk til et semiotisk træk, der associeres med voksensprog. Hvorvidt denne mulige og igangværende registergørelsesproces også afspejles i de unges og voksnes digitale sproglige praksisser i offentlige og semi-offentlige online kontekster, er et spørgsmål, der lægger op til fremtidige undersøgelser. Ydermere vil det være interessant at undersøge de sproglige generationsforskelle, vi peger på i denne artikel, på tværs af private og offentlige online kontekster samt kvantitativt på tværs af forskellige aldersgrupper.

Overordnet set kan vi på baggrund af denne undersøgelse konkludere, at hverdagsskriftsproget på de sociale medier er præget af sproglig variation og forskelligartethed, og at sproglige online stile er underlagt de samme registergørelsesprocesser, som vi også kender fra talesproget (se også Stæhr 2015b). Det forhold, at begge generationer genkender hinandens normer for sprogbrug og italesætter sproglige generationsforskelle, er ydermere interessant, idet det peger på, at digitalt medieret sprogbrug er blevet en normaliseret del af de unge og deres forældres hverdagsinteraktion. Vi kan således konkludere, at de unges forældre 
ikke blot har taget de sociale medier til sig - de er også blevet digitale sprogbrugere med deres egne karakteristiske (og måske endda stereotype) stilistiske normer og kommunikative træk.

Marianne Haugaard Hansen

Institut for Nordiske Studier og Sprogvidenskab, Københavns Universitet mariannehhansen@hotmail.com

Andreas Candefors Stæhr, lektor

Institut for Nordiske Studier og Sprogvidenskab, Københavns Universitet andst@hum.ku.dk

\section{TAK}

Projektet SoMeFamily er finansieret af Danmarks Frie Forskningsfond: Sapere Aude DFF-starting Grant.

\section{LITTERATUR}

Agha, A. 2007. Language and social relations. Cambridge: Cambridge University Press. DOI: $10.1017 /$ cbo9780511618284.006.

Andersen, E.M. 2015. What's your problem? Ph.d.-afhandling. Odense. Syddansk Universitet

Andersen, E.M., \& M. Rathje. 2019. Age and stage of life categorizations used to moralize in online social conflict. Discourse, Context \& Media 28. 19-26. DOI: $10.1016 /$ j.dcm.2019.02.001.

Androutsopoulos, J. 2011. Language change and digital media: A review of conceptions and evidence. T. Kristiansen \& N. Coupland (red.), Standard languages and language standards in a changing Europe, 145-161. Oslo: Novus.

Androutsopoulos, J. \& A. Georgakopolou. 2004. Discourse constructions of youth identities, 1-26. Amsterdam: John Benjamins. DOI: 10.1075/pbns.110.01and.

Androutsopoulos, J. \& A. Stæhr. 2018. Moving methods online: Researching digital language practices. A. Creese \& A. Blackledge (red.), The Routledge handbook of language and superdiversity, 118-132. London: Routledge.

Barton, D. \& C. Lee. 2013. Language online: investigating digital texts and practices. Abingdon: Routledge. DOI: 10.4324/9780203552308.

Blommaert, J. 2010. The sociolinguistics of globalization. New York: Cambridge University Press. DOI: 10.1017/cbo9780511845307. 
Cheshire, J. 2005. Age and generation-specific use of language. U. Ammon, N. Dittmar, K. Mattheier, \& P. Trudgill (red.), Sociolinguistics: an introductory handbook of the science of language and society, 1552-1563. Berlin: Mouton de Gruyter. DOI: 10.1515/9783110171488.2.8.1552.

Christensen, T.K., T.J. Jensen \& A.C. Stæhr. 2018. Funktionel grammatik: Grammatik i de sociale medier. A.C. Stæhr \& K.K. Mortensen (red.), Sociale medier og sprog: Analytiske tilgange, 61-92. Frederiksberg: Samfundslitteratur.

Coupland, N. 1997. Language, ageing and ageism. A project for applied linguistics? International Journal of Applied Linguistics 7. 26-48. DOI: 10.1111/j.14734192.1997.tb00102.x.

Coupland, N. 2004. Age in social and sociolinguistic theory. J.F. Nussbaum \& J. Coupland (red.), Handbook of communication and aging research. London: Routledge. DOI: 10.4324/9781410610171-11.

Danesi, M. 2017. The semiotics of emoji. The rise of visual language in the age of the internet. London: Bloomsbury Academic.

Danmarks statistik. 2018. It-anvendelse $i$ befolkningen. 1. november 2018. https:// www.dst.dk/Site/Dst/Udgivelser/GetPubFile.aspx?id=29448\&sid=itbef2018 (tilgået 28. august 2020)

Dragojevic, M., J. Gasiorek \& H. Giles. 2016. Accommodative strategies as core of the theory. H. Giles (red.), Communication accommodation theory: Negotiating personal relationships and social identities across contexts, 36-59. Cambridge: Cambridge University Press. DOI: 10.1017/cbo9781316226537.003.

Dresner, E. \& S.C. Herring. 2010. Functions of the nonverbal in CMC: Emoticons and illocutionary force. Communication Theory 20(3). 249-268. DOI: 10.1111/j.1468-2885.2010.01362.x.

Eckert, P. 1997. Age as a sociolinguistic variable. F. Coulmas (red.), The handbook of sociolinguistics. Oxford: Blackwell Publishers. DOI: 10.1002/9781405166256. ch9.

Ellison, N.B., \& D. Boyd. 2013. Sociality through social network sites. W.D. Dutton (red.), The Oxford handbook of internet studies, 151-172. Oxford: Oxford University Press. DOI: 10.1093/oxfordhb/9780199589074.013.0008.

Giles, H., N. Coupland \& J. Coupland. 1991. Accommodation theory. Communication, context, and consequence. H. Giles, J. Coupland, \& N. Coupland (red.), Contexts of Accommodation: Developments in Applied Sociolinguistics, 1-68. Cambridge: Cambridge University Press. DOI: 10.1017/cbo9780511663673.001. 
Goffman, E. 1955. On face-work. Psychiatry 18(3). 213-231. DOI: 10.1080/00332747.1955.11023008.

Gumperz, J. J. 1982. Discourse strategies. Cambridge: Cambridge University Press. DOI: $10.1057 / 9781137024930.0013$.

Hansen, M.H. 2021. Sproglige generationsforskelle på de sociale medier: En sproglig etnografisk undersøgelse af unge og deres foraldres sprogbrug online. Københavnerstudier i tosprogethed. København: Københavner Studier i tosprogethed.

Hougaard, T.T. 2004. Narmest en leg: En undersøgelse af sprog og interaktion i dansk webchat. Ph.d.-afhandling. Aarhus Universitet.

Hougaard, T.T. 2014. Sproglige forandringer i de nye medier: Fra chatstil til hashtagpoesi. Sprogbrug i de nye medier. NyS 46. 39-66. DOI: 10.7146/nys.v46i46.17524.

Hougaard, T.T. 2020. Emoji. Århus: Århus Universitetsforlag

Hyttel-Sørensen, L. \& A. Stæhr. 2014. Normativitet som social ressource på Facebook. Sprogbrug i de nye medier. NyS 46. 67-102. DOI: 10.7146/nys.v46i46.17525.

Jensen, J.N. \& M. Rathje. 2004. Rigtigt kort: Anbefalede forkortelser. København: Gyldendal

Jørgensen, J.N. 2001. Multi-variety code-switching in conversation 903 of the Køge project. J.N. Jørgensen. En køn strid. Sprog, magt og køn hos tosprogede børn og unge, 117-137. København: Roskilde Universitetsforlag,

Jørgensen, K.M. 2016. The media go-along: Researching mobilities with media at hand. MedieKultur: Journal of Media and Communication Research 60. 32-49. DOI: 10.7146/mediekultur.v32i60.22429.

Kemp, N., C. Wood \& S. Waldron. 2014. Do I know it's wrong: children's and adults' use of unconventional grammar in text messaging. Reading and Writing 27(9). 1585-1602. DOI: 10.1007/s11145-014-9508-1.

Labov, W. 1972. Sociolinguistic patterns. Philadelphia: University of Pennsylvania Press.

Lanza, E. \& K.V. Lexander. 2019. Family language ractices in multilingual transcultural families. S. Montanari \& S. Quay (red.), Multidisciplinary perspectives on multilingualism: The fundamentals, 229-252. Berlin: Mouton de Gruyter. DOI: 10.1515/9781501507984-011.

Leppänen, S. 2007. Youth language in media contexts: Insights into the functions of English in Finland. World Englishes 26(2). 149-169. DOI: 10.1111/j.1467971x.2007.00499.x. 
Lexander, K.V. \& J. Androutsopoulos. 2021. Working with mediagrams. A methodology for collaborative research on mediational repertoires in multilingual families. Journal of Multilingual and Multicultural Development 42 (1). 1-18. DOI: 10.1080/01434632.2019.1667363.

Livingstone, S. \& Haddon, L. 2009. Kids online: Opportunities and risks for children. Bristol: Policy Press. DOI: 10.2307/j.ctt9qgvds.6.

Madianou, M., \& D. Miller. 2013. Migration and new media: Transnational families and polymedia. London and New York: Routledge. DOI: $10.4324 / 9780203154236-4$.

Monka, M. 2018. Sociolingvistik: Sociolingvistik - Dialektbrug på tværs af online- og offlinekontekster. A.C. Stæhr \& K.K. Mortensen (red.), Sociale medier og sprog: Analytiske tilgange, 29-60. Frederiksberg: Samfundslitteratur.

Mortensen, K.K. \& A.C. Stæhr. 2018. Introduktion: Sprog og sociale medier. A.C. Stæhr \& K.K. Mortensen (red.), Sociale medier og sprog: Analytiske tilgange, 9-26. Frederiksberg: Samfundslitteratur.

Ochs, E. 1992. Indexing Gender. A. Duranti \& C. Goodwin (red.), Rethinking context: Language as an interactive phenomenon, 335-358. Cambridge: Cambridge University Press.

Pérez-Sabater, C. \& Montero-Fleta, B. 2015. A first glimpse at mobile instant messaging: Some sociolinguistic determining factors. Poznan Studies in Contemporary Linguistics 51(3). 411-431. DOI: 10.1515/psicl-2015-0016.

Rampton, B., J. Maybin \& K. Tusting (red.). 2007. Linguistic ethnography and interdisciplinarity. Opening the discussion. Journal of Sociolinguistics 11(5). DOI: 10.1111/j.1467-9841.2007.00340.x.

Rathje, M. 2010. Generationssprog. Dansk Sprognavns skrifter 43. København: Dansk Sprognævn.

Rathje, M. 2018. Genre og kontekst: Verbale kortformer i unges digitale tekster og skoletekster. A.C. Stæhr \& K.K. Mortensen (red.), Sociale medier og sprog: Analytiske tilgange, 93-120. Frederiksberg: Samfundslitteratur.

Rotne, L. 2009. LEET/1337, reverse eller popsprog? Om unges akrobatik på hjemmesiden Arto. Nyt fra Sprognavnet 2. 4-9.

Silverstein, M. 2003. Indexical order and the dialectics of sociolinguistic life. Language \& Communication, 23(3). 193-229. DOI: 10.1016/s0271-5309(03)00013-2.

Stark, L. \& K. Crawford. 2015. The conservatism of emoji. Work, affect, and communication. Social Media + Society. July-December. 1-11. DOI: $10.1177 / 2056305115604853$ 
Stæhr, A. 2015a. Sociale medier og hverdagssprog. F. Gregersen \& T. Kristiansen (red.). Hvad ved vi nu - om danske talesprog?, 153-164. København: Sprogforandringscentret.

Stæhr, A. 2015b. Reflexivity in Facebook interaction: Enregisterment across written and spoken language practices. S. Leppänen, J. Møller \& T. Nørreby (red.), Authenticity, Normativity and Social Media. Discourse, Context and Media 8. 30-45. DOI: 10.1016/j.dcm.2015.05.004.

Stæhr, A. 2016a. Normativity as a social resource in social media practices. L.M. Madsen, M.S. Karrebæk \& J.S. Møller (red.), Everyday languaging. Collaborative research on the language use of children and youth. Trends in Applied Linguistics, 71-94. Berlin: Mouton De Gruyter. DOI: 10.1515/9781614514800-004.

Stæhr, A. 2016b. Languaging and normativity on Facebook. K. Arnaut, M. Spotti \& M.S. Karrebæk (red.), Engaging superdiversity: Recombining spaces, times and language practices, 170-195. Bristol/Philadelphia: Multilingual Matters. DOI: 10.21832/9781783096800-010.

Stæhr, A.C. 2018. Sproglig etnografi: Refleksivitet og sociale medier. A.C. Stæhr \& K.K. Mortensen (red.), Sociale medier og sprog: Analytiske tilgange, 217-251. Frederiksberg: Samfundslitteratur.

Stæhr, A.C. \& T.R. Nørreby. Under udgivelse. The metapragmatics of mode alternation. J. Androutsopoulos (red.), Polymedia and digitally mediated interaction. Pragmatics \& Society.

Tagg, C. \& P. Seargeant. 2017. Negotiating social roles in semi-public online contexts. S. Leppänen, E. Westinen \& S. Kytölä (red.), Social media discourse, (dis)identifications and diversities, 211-234. New York: Routledge. DOI: $10.4324 / 9781315624822$.

Thurlow, C. 2006. From statistical panic to moral panic. The metadiscursive construction and popular exaggeration of new media language use in the print media. Journal of Computer Mediated Communication 11(3). 667-701. DOI: 10.1111/j.1083-6101.2006.00031.x. 
Transskriptionsnøgle

Uddragene er udskrevet efter følgende konventioner:

(.) Kort pause

(tal) Pause - tallet markerer antal sekunder

ha Latter

ord! $\quad$ Emfase

XXX Uforståelig tale

o:rd Forlængelse af lyd

ord- Uafsluttet ord

((ord)) Kommentar

[...] Udeladte passager

"ord" Stiliseret udtale 
